\title{
'Land for Those Who Work It': A Visual Analysis of Agrarian Reform Posters in Velasco's Peru
}

\author{
ANNA CANT*
}

Abstract. Latin American military dictatorships of the twentieth century were often right-wing, elitist and violent. A marked exception was the left-wing Peruvian military government of Juan Velasco Alvarado. More exceptional still was the government's use of visual media. Between 1968 and 1970 it produced approximately 20 posters, printed in editions of 50,000 to 200,000, to promote the radical Agrarian Reform Law. These posters provide vibrant representations of the agrarian reform's ideological aspects, which have been under-studied. A detailed exploration of visual communication shows that the government deployed aesthetically sophisticated propaganda and symbols to encourage social participation in the reform.

Keywords: Peru, Juan Velasco Alvarado, agrarian reform, posters, pop art, op art

\section{Introduction}

On 3 October i 968, General Juan Velasco Alvarado led a successful military coup to depose the democratically elected administration of Fernando Belaúnde Terry, under whom he had served as commander of the armed forces. By i 968 Peru had already experienced seven successful military coups in the twentieth century. The self-titled Gobierno Revolucionario de las Fuerzas

Anna Cant is a PhD student in the History Faculty at the University of Cambridge. Email: annacant@googlemail.com.

* Research for this article was made possible by financial support from the Arts and Humanities Research Council. The images that accompany it are used by kind permission of Jesús Ruiz Durand, the original artist, who holds the copyright to the posters. I first accessed these posters in the Sam L. Slick Collection of Latin American and Iberian Posters, Center for South West Research, University Libraries, University of New Mexico, which holds the copyright to the digital images. The posters are reproduced here in monochrome; by kind permission of Jesús Ruiz Durand they can be seen in colour on the JLAS website at www.journals.cambridge.org/las.

I would also like to thank Jesús Ruiz Durand, Alfonso Salcedo, Héctor Béjar, Mirko Lauer and Gustavo Buntinx for sharing their thoughts and insights with me during field research in Lima. I am grateful to the $J L A S$ 's anonymous reviewers, whose detailed comments have strengthened the original manuscript considerably, and I extend my thanks to my supervisor, Dr. Gabriela Ramos. 
Armadas (Revolutionary Government of the Armed Forces, GRFA) was fundamentally different from previous military governments, however, as it was an institutional movement rather than one centred on a single general or charismatic caudillo. ${ }^{\mathrm{I}}$ Moreover, the GRFA came to power with a strong agenda of left-wing reforms. Allied to this radical agenda was a determination to use the power of popular mobilisation to defeat the oligarchy, which had done so much to halt the progress of agrarian reform under Belaúnde's government. Between 1968 and 1970 the government created approximately 20 posters, printed in editions of 50,000 to 200,000, to promote a radical Agrarian Reform Law. ${ }^{2}$ These posters, produced by the Dirección de Difusión de la Reforma Agraria (Office for Dissemination of the Agrarian Reform, DDRA), made captivating use of visual complexity and unorthodox imagery, which as David Craven suggests, were intended to stimulate political thought amongst the masses. ${ }^{3}$

In many countries across Latin America, agrarian reform attempted to reduce the power of the landowning elites and increase economic productivity. Rapid demographic growth had increased the demand for equal access to land, while the "generally "archaic" agrarian structure of Latin America was identified by the Economic Commission for Latin America in Development Problems in Latin America ... as a major obstacle to economic development'. ${ }^{4}$ In Peru, popular politics had been growing since the beginning of the twentieth century. This increased political consciousness was a crucial resource for the Velasco government (1968-75) and served as a platform from which agrarian reform was launched. The posters were part of the government's attempt to project a particular interpretation of the reform and maintain public support for its objectives, during what would potentially be a slow process of land expropriation and legal arbitration. As Harriet Evans and Stephanie Donald have written, posters are 'an exceptional visual form in that their function and design are geared to instant comprehension by a large proportion of the population. In order to do this they rely on shortcuts to create an immediate political or emotional

${ }^{1}$ Liisa L. North, 'Ideological Orientations of Rulers', in Cynthia McClintock and Abraham F. Lowenthal (eds.), The Peruvian Experiment Reconsidered (Princeton, NJ: Princeton University Press, I983), pp. 245-74.

2 Figures cited by Teresa Eckmann, 'The Latin American Poster: Image, Message, and Means', in Russ Davidson (ed.), Latin American Posters: Public Aesthetics and Mass Politics (Santa Fe, NM: Museum of New Mexico Press, 2006), p. 38.

3 David Craven, 'Latin American Posters: Public Aesthetics and Mass Politics', in Davidson (ed.), Latin American Posters, p. I 6.

${ }^{4}$ Norman Long and Bryan Roberts, 'Agrarian Structures', in Leslie Bethell (ed.), The Cambridge History of Latin America, vol. I I: Bibliographical Essays (Cambridge: Cambridge University Press, I 995), p. 564. 
impression.'s Examining these 'shortcuts' can help identify which images and ideas were most resonant at the time.

In contrast to earlier posters in Peru, which had tended to focus on charismatic political leaders, there was a notable absence of military or government figures in the agrarian reform posters. ${ }^{6}$ The use of bright colours and modern designs characterised the agrarian reform as a moment of hope and optimism. Slogans such as 'Land without masters' and 'We are free, the revolution is giving us land' put forth an emancipatory vision of a 'new Peru', articulating the government's aspirations towards a more equal and integrated society. While the socio-economic consequences of the reform have been examined extensively, the posters provide a vibrant representation of the ideological and cultural aspects of the reform, which have remained understudied.

Writing in 2003, Susan Tschabrun, an archivist, noted that 'The last few years have seen an explosion of research on political posters across a number of disciplines - social, cultural, and art history; political science, communication, and gender studies - compared to the trickle of studies that had made it into print over the previous thirty years.' 7 In the case of Latin America, however, the attention given to collecting, preserving and exhibiting political posters has not translated into sustained studies of their historical significance. ${ }^{8}$ This reticence may be attributable in part to the fact that, as Susan Sontag wrote, 'Unlike the public notice, whose function is unambiguously to say something, the poster is not concerned ultimately with anything so clear or unequivocal.' Indeed, part of the power of the poster as a means of political communication is its ability to suggest several things at once. Visual representations of the peasantry, an emphasis on modernity and the (re)formulation of a set of national symbols were all prominent within the Peruvian posters. By providing a visual analysis of the agrarian reform posters, this article aims to complement the work of scholars such as Enrique Mayer and Linda Seligmann on the narrative dimensions of the

5 Harriet Evans and Stephanie Donald (eds.), Picturing Power in the People's Republic of China: Posters of the Cultural Revolution (Oxford: Rowman \& Littlefield, I999), p. I 8.

${ }^{6}$ For example, a 193 I election poster produced by the Alianza Popular Revolucionaria Americana (American Popular Revolutionary Alliance, APRA) featured a giant Haya de la Torre and throngs of people with outstretched arms below him, accompanied by the phrase, 'Only Aprismo can save Peru': see Steve Stein, Populism in Peru: The Emergence of the Masses and the Politics of Social Control (Madison, WI: University of Wisconsin Press, I 980), p. I77.

7 Susan Tschabrun, 'Off the Wall and into a Drawer: Managing a Research Collection of Political Posters', The American Archivist, 66 (2003), p. 306.

${ }^{8}$ Gustavo Buntinx has written a number of excellent essays that discuss the Peruvian agrarian reform posters. However, his approach is primarily focused on the concerns of art criticism, rather than the role of the posters within the political communication of the GRFA.

9 Susan Sonntag, introductory essay in Dugald Stermer and Susan Sontag, The Art of Revolution: 96 Posters from Cuba (London: Pall Mall, 1970), p. x. 
reform. ${ }^{\text {10 }}$ The approach adopted here places the posters in dialogue with other source materials, including interviews, government-produced pamphlets and newspapers. In doing so, the paper demonstrates that the posters reflected major tensions in Peruvian politics and society, resonating with the public and forging persuasive and compelling symbols of the agrarian reform that contributed to mass mobilisation.

\section{The 1969 Agrarian Reform}

A brief comparison of Velasco's agrarian reform with that of his immediate predecessor, President Belaúnde, indicates the huge increase in the Velasco plan's extent and scale. During Belaúnde's five-year presidency, 2,625 families had received state-allocated land, usually of poor quality. By contrast, between 1969 and 1974, I75,000 families received 4.5 million hectares. ${ }^{11}$ The 1969 reform was also larger in scope and more swiftly implemented than agrarian reforms in other Alliance for Progress countries. ${ }^{12}$ In fewer than ten years it succeeded in bringing an end to private latifundismo and introducing a comprehensive system of cooperative farms. These were designed to introduce more democratic systems of labour organisation and establish a state-led agricultural production network that could respond better to the growing global demand for foodstuffs. When it was introduced eight months after the 1968 coup, the agrarian reform was the first major sign of radicalism on the part of the government and hence a testing ground for ideology and praxis. The law stipulated that land holdings over a particular number of hectares (variable according to the geography and predominant mode of production of the region) would be expropriated by the state and vested in the hands of a series of cooperatives, which would take full ownership of the land once they had finished paying off the debt due to the state for the cost of expropriation. While the expropriations were compulsory, landowners received payment for

1o Enrique Mayer, Cuentos feos de la reforma agraria peruana (Lima: Instituto de Estudios Peruanos/Centro Peruano de Estudios Sociales, 2009); Linda J. Seligmann, Between Reform \& Revolution: Political Struggles in the Peruvian Andes, I969-I9gI (Stanford, CA: Stanford University Press, 1995). Mayer used oral history interviews to explore different accounts of the agrarian reform, as told by government figures, cooperative leaders, wealthy landowners and landless peasants. Using legal records, Linda Seligmann demonstrated the significance of particular social and political narratives in the adjudication of land disputes that followed from the agrarian reform.

${ }^{11}$ Guillermo de la Peña, 'Rural Mobilizations in Latin America since c. 1920', in Leslie Bethell (ed.), The Cambridge History of Latin America, vol. 6: Latin America since 1930: Economy, Society and Politics, part 2 (Cambridge: Cambridge University Press, 1994), pp. 459-60.

${ }_{12}$ The Alliance for Progress was a programme initiated by President John F. Kennedy in $196 \mathrm{I}$ that aimed to establish economic cooperation between the United States and South America. Its priorities included an increase in per capita income, the introduction of democratic governments, more equitable income distribution and land reform. 
their lands in the form of industrial bonds and/or cash, following a detailed assessment of the value of the land by government administrators.

Occurring at a time when dependency theory and development economics were in vogue, the 1969 Peruvian agrarian reform attracted international attention. Some of the earliest assessments of the reform appeared in a volume of essays by Peruvian and international specialists edited by Abraham F. Lowenthal. ${ }^{13}$ Its title, The Peruvian Experiment, aptly captured the extent to which the Peruvian case departed from the path of agrarian reform set down in Mexico, Bolivia and Ecuador, where land redistribution had resulted from popular struggle. While notions of social justice and equality featured heavily in the rhetoric of the GRFA, the 1969 Ley de Reforma Agraria (Agrarian Reform Law) was, crucially, driven by a long-term change in military priorities rather than a popular political movement. The onset of the Cold War gave prominence to the threat of internal insurgency, following developments in Cuba, Vietnam and Bolivia. Military education reflected this shift. Teaching at the Centro de Altos Estudios Militares (Centre for Advanced Military Studies, CAEM), a military academy established in 1950, focused on the importance of economic development to improving social integrity, reducing the threat of insurgency and guaranteeing an effective national response to total warfare. The military's commitment to economic development was reinforced by soldiers' experiences of combating guerrillas in Peru's deprived interior, particularly during the 1965 uprising of the Movimiento de Izquierda Revolucionaria (Revolutionary Left Movement, MIR), a splinter group originating in the Alianza Popular Revolucionaria Americana (American Popular Revolutionary Alliance, APRA). As José María Caballero commented, 'Revolution from above was seen by these officers as a way to preempt revolution from below.' ${ }^{14}$

The agricultural cooperatives established by the Agrarian Reform Law took two forms: cooperativas agrarias de producción (agrarian production cooperatives, CAPs) and sociedades agricolas de interés social (agrarian social interest societies, SAISs). The principal difference between these was that while each CAP was composed of permanent labourers who were jointly responsible for managing a single estate, the SAIS was a broader association made up of permanent labourers from a number of neighbouring estates, as well as local communities who did not contribute land, capital or labour to the estates concerned but could nevertheless participate in the management of these estates and receive a share of the profits. By extending SAIS membership to

${ }^{13}$ Abraham F. Lowenthal (ed.), The Peruvian Experiment: Continuity and Change Under Military Rule (Princeton, NJ: Princeton University Press, 1975).

${ }^{14}$ José-María Caballero, 'From Belaúnde to Belaúnde: Peru’s Military Experiment in ThirdRoadism', Working Paper no. 36 (Cambridge: Centre of Latin American Studies, Cambridge University, I98I), p. 8. 
communities living in areas surrounding the expropriated estates, the government hoped to broaden the range and impact of the reform and provide recompense to indigenous communities in particular, which had historically suffered encroachment on their lands from powerful hacendados. ${ }^{\text {Is }}$ However, as Linda Seligmann has observed, 'Seventy-five percent of the rural population did not qualify for membership in these enterprises and were thus excluded from the reform, receiving no, or only indirect, benefits from it.' ${ }^{16}$ This was often because these individuals belonged to informal peasant groups that were not recognised by the government, or because they were categorised as temporary rather than permanent estate workers.

A further problem, besides the limited coverage of the cooperatives, was that the mode of agricultural production envisioned by the GRFA took almost no account of existing forms of production and posited large-scale capital-intensive production as the solution for a wide variety of geographical areas. Against a background of rapid urbanisation, this style of production offered a means both to guarantee food supplies to cities and to improve agricultural incomes, which would in turn create demand for industrial products. The GRFA believed that introducing economies of scale and mechanisation would raise the productivity of Peruvian agriculture and make its exports more competitive on international markets, despite serious limitations in the transportation network and a lack of technical expertise. Moreover, the cooperative practices that underpinned the reform were difficult to instil among populations that often had a long history of disputes over access to land and water, and that held their own views about how the land should be distributed and organised. ${ }^{17}$

The difficulty of simultaneously stimulating participation in agrarian cooperatives while pushing forward the government's agenda of capitalintensive modernisation created a number of contradictions in the implementation of the reform. Reporting on the earliest cooperatives, on the sugar plantations of Tumán, Cayaltí and Laredo, Ramón Zalidívar observed:

Assemblies were formed with $\mathrm{I} 20$ delegates, but not all of them were elected by the workers. In Tumán the government took it upon itself to appoint ninety-eight out of the I20, in Cayaltí twenty-eight and in Laredo seventy-six. The justification of the procedure was that by guaranteeing the redemption of the bonds, they had put the national interest at stake, and therefore had to appoint the delegates in order to safeguard it. ${ }^{18}$

is Seligmann, Between Reform \& Revolution, p. 59.

${ }^{16}$ Ibid., p. 6o, citing Francisco Moncloa, 'Presentación: la realidad del campo y el modelo de desarrollo industrial', in Carlos Amat y León (ed.), Realidad del campo peruano después de la reforma agraria (Lima: Centro de Investigación y Capacitación and Editora Ital Perú, 1980), pp. I I-I 6 .

${ }^{17}$ Seligmann, Between Reform \& Revolution, pp. 77-92.

${ }^{18}$ Ramón Zalidívar, 'Agrarian Reform and Military Reformism in Peru', in David Lehmann (ed.), Agrarian Reform and Agrarian Reformism (London: Faber \& Faber, 1974), pp. 25-70. 
Furthermore, the range of decisions in which members of the cooperative could participate was largely restricted to administrative matters, rather than production techniques and strategies. Thus, despite the introduction of selfgoverning cooperatives, the methodology for management of agricultural estates continued to be governed by a top-down chain of command. ${ }^{19}$

Having campaigned for land reform for decades before the i 969 law, many campesinos became frustrated at the pace of its implementation and the fact that a number of landlords successfully avoided the expropriation of their lands by engaging in 'parcelisation', the sale or redistribution of lands into smaller plots so that their total estate did not reach the limit set out in the reform. The case of Huando, an orange-growing hacienda in the Chancay valley, is particularly illustrative of the kinds of conflicts that ensued from the reform. The owners of the hacienda, comprising I,860 hectares and 533 workers, began dividing up their lands into 68 lots during the government of Belaúnde. The workers objected, arguing that at least 50 per cent of the total area should be divided into lots of not less than 9 hectares in order to facilitate collective farming. In October 1970 the union called a strike that lasted I 20 days, and in February I97 I one group of workers clashed with police while another took refuge in the National Agrarian University at La Molina. On 4 February I 97 I the government annulled the parcelisation of the estate. Following a series of protests like the one that took place in Huando, the government was forced to introduce new rules regarding the parcelisation of land, to the effect that a plot had to be reserved as common land for the permanent workers before an estate could be divided up, and a larger number of smaller properties were to be formed to increase access to land. This change was not backdated, however, and lands that had already been parcelled up could not be expropriated for cooperative use. ${ }^{20}$ Weaknesses in the reform legislation, particularly in the early stages, limited the speed and extent of land expropriation, even in areas where there was considerable popular support for the idea of agricultural cooperatives.

The Huando case illustrates how government policy on agrarian reform, as in other areas (for example, the nationalisation of Peru's oil fields and refineries, the Ley de Comunidad Industrial (Law of Industrial Community) and the policy of propiedad social, 'social property'), was not preordained from the start, but rather often developed on an ad-hoc basis in response to political pressure and economic circumstances. ${ }^{21}$ Writing in 1974, Colin Harding

19 Uta Schirmer, 'Reforma agraria y cooperativismo en el Perú: cambios estructurales y contradicciones de la nueva política agraria del gobierno militar del Perú', Revista Mexicana de Sociología, 39: 3 (1977), p. 808.

${ }^{20}$ Zalidívar, 'Agrarian Reform and Military Reformism in Peru', p. 4I.

${ }^{21}$ The 1970 Ley de Comunidad Industrial obliged company owners to establish industrial communities' to act as the legal representative of the workers; Empresas de Propiedad Social 
observed that the agrarian reform had gradually been pushed to the left, becoming more radical and comprehensive in response to rural protests. When confronted with land occupations, the reform authorities were 'forced to accept a fait accompli, expropriate the land very quickly and hand it over to a cooperative of the permanent and temporary labourers, despite the fact that invasions [were] expressly defined as an act of sabotage against the agrarian reform'. ${ }^{22}$ Moreover, the government often seemed to be experimenting with a variety of measures to satisfy the (unanticipated) demands of those excluded by the 1969 law. In the coastal valleys these included the creation of a General Inspectorate of Agrarian Reform to identify and evaluate conflicts in the countryside, obligatory management-sharing schemes for farms unaffected by the agrarian reform, and the expropriation of estates where a lack of compliance with existing labour legislation could be demonstrated. ${ }^{23}$

Anger and frustration at the way in which the GRFA implemented its agrarian reform were heightened by the hopes and expectations that the announcement of the Agrarian Reform Law had aroused among the peasantry. The rhetoric used to promote the reform cast it as a moment of triumph for the peasant and the end of an era of social and economic oppression. The fact that the GRFA was able to implement its reform on such a large scale was due in large part to its ability to retain support from the peasants, which acted as a counterweight to the power of the oligarchy. Velasco famously declared: 'Campesino, the master will no longer eat of your poverty!' In practice, however, there was a lack of cultivable land and technical expertise, and high levels of prior conflict regarding land and grazing rights both slowed the process of land redistribution and stymied the work of the cooperatives once they were in operation. In 1971 , according to figures published in the Peruvian Times, 'there was enough land on the coast to create 79,916 farms, and 171,000 families qualified to receive one; in the Sierra the picture was even worse: 69,622 farms and 681,000 families'. ${ }^{24}$ Moreover, as Caballero has observed, there was a 'disequilibrium between the reduced economic significance of the agricultural sector and its large social importance'. While a high proportion of the labour force continued to be engaged in agriculture, it made a relatively small contribution to Peru's gross domestic product. ${ }^{25}$ Against this

(Social Property Companies) were created in 1974 as cooperative economic units to give workers equal say in the running of companies and the distribution of profits. For the dynamics of policy-making within the Velasco government, see George D. E. Philip, The Rise and Fall of the Peruvian Military Radicals, 1968-1976 (London: Athlone Press, 1978).

${ }^{22}$ Colin Harding, Agrarian Reform and Agrarian Struggles in Peru (Cambridge: Centre of Latin American Studies, I 974), p. I 3.

${ }^{23}$ Ibid., p. 7.

${ }^{24}$ Ibid., p. I 2. The figures come from an official study quoted in the Peruvian Times, i I Feb. I97I.

${ }^{25}$ Caballero, 'From Belaúnde to Belaúnde', p. 25. 
background, the tension between inspiring interest in land reform among the peasantry and retaining strict administrative control was to become a defining feature of the mass communications methods deployed by the GRFA.

\section{Popular Mobilisation}

To interpret the significance and role of the agrarian reform posters as a form of government communication, it is important to understand their position within the chronology of the revolution. In 1968 there had been no plan for how to mobilise the population. In constructing his government, Velasco used traditional military principles, distributing major government departments among the three armed forces and building a bureaucracy based on militarystyle command structures. When it came to political mobilisation, however, there was considerable uncertainty about how best to proceed. Henry Dietz observed that for the first i 8 months following the i 968 coup, the government made little effort to organise and mobilise the population, and relied on vague requests for support. ${ }^{26}$

This uncertainty was caused by significant political diversity within the government. Liisa North argues that the class and sectoral conflicts provoked by the agrarian reform led to 'a process of ideological differentiation' within the GRFA. ${ }^{27}$ While the military's shared commitment to agrarian reform had created important common ground, ideological differences came to the fore once the reform was under way. The two poles of this divergence were represented by General Leonidas Rodríguez Figueroa on the left and General Javier Tantaleán Vanini on the extreme right. While Rodríguez argued that 'mobilisation began with a critical "questioning" by the powerless masses of their role in the society' and continued on to 'a substantive alteration of the structure of power', the discourse of the rightist faction 'consisted of agitational and insistent demands for participation to support the revolutionary government through the appropriate hierarchically organised channels'. ${ }^{28}$

The tension between these viewpoints was to some extent resolved in I97 I by the establishment of the Sistema Nacional de Apoyo a la Movilización Social (National System of Support for Social Mobilisation, SINAMOS), which combined a rigid, military-style command structure with an important discourse on social mobilisation. The aim of SINAMOS was to achieve the

${ }^{26}$ Henry Dietz, 'Bureaucratic Demand-Making and Clientelistic Participation in Peru', in James M. Malloy (ed.), Authoritarianism and Corporatism in Latin America (Pittsburgh, PA: University of Pittsburgh Press, i 977), p. 417.

${ }^{27}$ North, 'Ideological Orientations of Rulers', p. 252.

${ }^{28}$ Ibid., pp. 252-7, citing quotations from Correo, 25 July 197 I. 
conscious and active participation of the national population in the tasks demanded by economic and social development'. ${ }^{29}$ More specifically, its objectives were 'the training, orientation and organisation of the population; the development of social interest organisations; and communication, particularly dialogue between the government and the population'. ${ }^{3 \circ}$ The acronym deliberately incorporated the words 'sin amos' ('without masters') to reflect the kind of grassroots participation it aimed to facilitate. In practical terms SINAMOS was composed of national, regional, zonal and local tiers, with offices across the country and a chain of command leading up to General Leonidas Rodríguez Figueroa, who was directly accountable to Velasco. The scale of the operation and the numbers of people involved in SINAMOS were without precedent in Peru's history. At its peak, SINAMOS employed over 2,500 public officials and had at least 400 zonal offices distributed throughout I I regions.

Though SINAMOS was particularly significant due to the scale and extent of its operations, and the way in which it grappled with questions of popular participation, it only emerged three years after the revolution, and was not planned from the outset. In fact, as Mirko Lauer commented in interview, many of the militares had never considered that their communications strategy would have to be permanent. ${ }^{3}$ Thus the interval between the coup in 1968 and the establishment of SINAMOS three years later is particularly interesting, as it was the major period in which the GRFA's ideas on popular mobilisation were forming. Out of this period emerged the innovative and experimental agrarian reform posters, which should therefore be understood as part of evolving efforts to engage the population, rather than a fully developed system of propaganda. Before examining them in greater detail, it is necessary to outline some of the major debates surrounding the government's approach to political mobilisation.

Early assessments of the GRFA concluded that for all its rhetoric of popular participation, the government was essentially an exercise in corporatism, a system in which political activity is channelled through topdown structures that maintain vertical control while facilitating individuals' participation in locally oriented socio-political associations. ${ }^{32}$ In the volume of essays edited by Abraham F. Lowenthal, Julio Cotler charged the government with deliberately engineering the political demobilisation of the working classes, while Jane Jaquette identified a dangerous trend towards

29 SINAMOS, Movilización social: el inicio de una nueva etapa fundamental (Lima: SINAMOS, I 97 I), pp. 3-4.

30 Ibid.

${ }^{31}$ Interview with Mirko Lauer, journalist and active member of the collective that produced the posters, I 2 April 20 io.

32 Alfred Stepan, The State and Society: Peru in Comparative Perspective (Princeton, NJ: Princeton University Press, 1978), p. 46. 
authoritarianism. ${ }^{33}$ However, these assessments imply a deliberate agenda of political control, obscuring the varied approach that the GRFA took to popular mobilisation and understating some potentially legitimate reasons for continued state control, such as the need to arbitrate in areas where land was in high demand and the desire to modernise agricultural production. Cotler and Jaquette's confidence in liberal democratic notions of political participation, emphasising a dissociation between public institutions and political activity, excludes the possibility of popular participation facilitated by the state.

José Carlos Fajardo, on the other hand, notes that under the Velasco government, 'the growth of the state was accompanied by measures that limited its power and developed that of the people'. ${ }^{34}$ While the Agrarian Reform Law established a process of hegemonic agrarian development based on a state-led system of cooperatives, it also provided the tools with which campesinos could align state hegemony with their own interests. The provision of free legal assistance was particularly significant in this respect. Campesinos were also guaranteed a public defender who was fluent in Quechua, and they were allowed to present their testimony orally at the agrarian tribunals that resolved land disputes. Linda Seligmann, who studied the legal records produced during the course of land disputes in Cusco, found that although the state defined the terms of land entitlement, peasants 'demonstrated a remarkable capacity to seize upon the written word and to interpret the complexities of legal tenets in ways that conformed both to existing principles of justice and to the peasants' immediate objectives. 35 Government measures to encourage popular participation in agrarian reform created a new political landscape for a considerable proportion of the population, and the opportunities provided by this environment should be considered alongside objections to its mechanisms.

While the GRFA was criticised by the Left for being insufficiently radical, the Right accused it of pursuing a reckless agricultural policy. Writing in 1977, Enrique Chirinos Soto and Guido Chirinos Lizares contrasted the Velasquista reforms with Belaúnde's agrarian reform, which they described as 'a constitutional, legal, democratic, peaceful process without violence'. ${ }^{36}$ They argued that land reform was an inevitable development in Peru's history, and

33 See Julio Cotler, 'The New Mode of Political Domination', in Lowenthal (ed.), The Peruvian Experiment, pp. 44-78; and Jane S. Jaquette, 'Belaúnde and Velasco: On the Limits of Ideological Politics', in Lowenthal (ed.), The Peruvian Experiment, pp. 402-37.

34 José Carlos Fajardo, Organización y participación politica en el Perú, antes y durante el gobierno de Juan Velasco Alvarado (Lima: Editorial Universitaria, 2009), p. 3 I 2.

35 Seligmann, 'The Burden of Visions amidst Reform: Peasant Relations to Law in the Peruvian Andes', American Ethnologist, 20: I (1993), p. 25.

${ }^{36}$ Enrique Chirinos Soto and Guido Chirinos Lizares, El septenato 1968-75 (Lima: Alfa, 1977), pp. 300-I. 
that therefore the speed and scale of expropriations during the agrarian reform caused unnecessary political and economic instability. Gonzalo Portocarrero has attacked this interpretation as a fundamental misreading of the political tensions that characterised the era. The belief that the agrarian reform was misguided and wrong has, he argues, led to a 'banal history' that treats the Velasco government as a one-dimensional, power-hungry dictatorship. ${ }^{37}$ Closer attention to the administration's methods of popular mobilisation, such as the agrarian reform posters, helps to provide a more nuanced account of its ideology and politics.

Aware of the strength of conservative opposition to its policies, the GRFA fought hard to dismantle the oligarchy, which exerted a powerful presence through newspapers such as Expreso and La Prensa. As the rural elites progressively lost their assets during the agrarian reform, and their presence in the political parties dwindled, the media became a stronghold of conservatives and the upper classes. The degree of antagonism between the GRFA and the newspapers resulted in a series of laws to curb the latter's power, beginning with the banning of newspaper ownership by non-Peruvian nationals in 1969 . The culmination of this struggle came in 1974 with the expropriation of all national daily newspapers and their redistribution among different sectors of civil society. ${ }^{8}$ In practice, this system did not last - in August 1975 Velasco was replaced by General Francisco Morales Bermúdez, who returned the newspapers to private ownership-but it was a radical response to the structural dominance of the oligarchy.

The strength of opposition to its policies from both the Right and the Left helps to explain why the government felt it necessary to construct such a largescale political and social organisation as SINAMOS. The remit of SINAMOS was extremely broad: some units were responsible for fostering the arts, while others were engaged in training and administering the agrarian cooperatives created by the agrarian reform. The novelty of what was being implemented prompted the government to publish numerous articles and pamphlets setting out what the organisation sought to achieve, and trying to fend off accusations of both fascism and communism. ${ }^{39}$

In addition to a new style of community organising, SINAMOS drew on new currents in the theory and practice of education, such as Paulo Freire's

37 Gonzalo Portocarrero, 'Memorias del Velasquismo', in Marita Hamann, Santiago López Maguiña, Gonzalo Portocarrero and Víctor Vich (eds.), Batallas por la memoria: antagonismos de la promesa peruana (Lima: Red para el Desarrollo de las Ciencias Sociales en el Perú, 2003), p. 250.

${ }^{8}$ Juan Gargurevich Regal, Historia de la prensa peruana, I594-I9go (Lima: La Voz, I991), pp. $201-20$.

39 See, for example, SINAMOS, Movilización social: ¿de quién y para qué? (Lima: SINAMOS, 1972); and ¿Por qué se ataca al SINAMOS? (Lima: SINAMOS, 1974). 
'pedagogy of the oppressed'.$^{\circ}$ Freire challenged the power differential between teacher and student, arguing that both parties should be engaged in learning from one another. Breaking down the power dynamics of traditional teaching methods could make education a more broadly empowering process. Freire visited Peru on several occasions during the Velasco government, and his influence is particularly evident in a series of illustrated pamphlets produced by SINAMOS on the basic principles of the revolution. Designed to be read in a group setting, these pamphlets included discussion questions such as: 'How and in what way will popular participation make the conquests of the revolution irreversible?' ${ }^{\prime}$ I By stimulating the exchange of ideas, these questions aimed to put Freire's principles into practice. Similarly, the introduction to 8 preguntas a la Revolución Peruana stated:

In this pamphlet you will find some questions and their answers. They are for you to think about. It could be that you agree with what is said here and it could be that you do not. They are not orders, nor instructions, nor official truths. They are material for study and discussion for you and your family, your friends, and your colleagues at work and school. ${ }^{42}$

At the same time, however, the format of pre-prepared questions and answers was reminiscent of methods long established in religious education, such as the catechism manual. The pamphlets therefore reflected a mixture of social liberationist ideas and authoritarianism. This paradox could also be found in the hierarchical structure of SINAMOS (a supposedly grassroots-led organisation), in the government's contradictory statements on political participation - and in the agrarian reform posters, as will be discussed in the following sections.

\section{The Power of the Poster}

The three decades from the i 960 s to the i 990 s have been called the 'golden age of the poster' in the Americas. ${ }^{43}$ The prominence and significance of posters in Latin America during this period was due to a combination of social change and technological innovation. The widespread introduction of the silkscreen allowed poster artists to combine media, such as photographs and painting, in order to create interesting visual effects. Rapid urbanisation and industrialisation created new audiences for the street poster and a boom in the advertising industry. Posters also reflected a growing international trend

${ }^{4}$ Paulo Freire (trans. Myra Bergman Ramos), Pedagogy of the Oppressed (New York: Continuum, 2003). First published in Portuguese in 1968 as Pedagogia do oprimido.

${ }^{41}$ SINAMOS, Proceso revolucionario: logros de la Revolución Peruana (Lima: SINAMOS, I 972 ).

42 SINAMOS, 8 preguntas a la Revolución Peruana (Lima: SINAMOS, 1973).

${ }^{43}$ Craven, 'Latin American Posters', p. I 5. 
favouring artistic expression outside of the gallery or museum. The Cuban posters produced following the 1959 revolution were particularly influential because of both their innovative design techniques and their international appeal, incorporating a wide variety of artistic movements such as pop art, op art, minimalism and conceptual art, as well as the earlier avant-garde techniques of collage, montage and surrealism. ${ }^{44}$ As David Craven has written, 'This new aesthetic commitment to an experimental, open-ended engagement of diverse cultural traditions was invited by the early opposition of Cuban leaders like Che Guevara and Fidel Castro to the Stalinist doctrine of "Social Realism".'45 In this respect, Cuban art broadened the possibilities of what posters could achieve.

Inspired by the successes in Cuba, in 1968 the GRFA established the Dirección de Difusión de la Reforma Agraria. Led by an experienced Cusqueño journalist, Efraín Ruiz Caro, it comprised a small team of publicists, artists and writers, including Jesús Ruiz Durand, Mirko Lauer, José Bracamonte, Emilio Hernández Saavedra and José Adolph. These individuals were already enjoying successful careers in their respective fields. Lauer was a published poet, while Ruiz Durand had exhibited work in the Museum of Modern Art in New York. Their decision to support the agrarian reform was principally ideological.

After the new agrarian reform was announced in June 1969, there was an urgent need to inform people about land expropriation procedures. In interview, Ruiz Durand captured both the practical function performed by the posters and the speed with which they had to be produced:

The law was made, so they had to hand over the lands in Cusco, in the sugar haciendas, in Huancayo, in the north, in the south, in the centre ... And there were lots of these ceremonies for the handing over of lands. So it was necessary to make pamphlets, to make posters, to make flyers, to take photographs, film, make magazines, etc. But [it had to be done] now, in moments. There was no time to plan: 'Tomorrow we're going to Cusco and we need 5,000 posters, 20,000 posters, I00,000 posters; for the north, for the centre, for the south.' It had to be done in two days, in three days, and to go there as well. So it was a very dynamic thing. ${ }^{46}$

Although SINAMOS later absorbed the DDRA into its organisational structure and continued to produce posters as part of its communications efforts, the activities of the DDRA from 1968 to I 970 were part of a unique moment in the history of the military government, when its ideas regarding popular mobilisation were still very much in flux. The subsequent analysis focuses, in particular, on the posters designed by Jesús Ruiz Durand.

${ }^{44}$ David Craven, Art and Revolution in Latin America, Igro-rggo (New Haven, CT: Yale University Press, 2002), p. 95.

45 Ibid.

${ }^{46}$ Interview with Jesús Ruiz Durand, 30 March 20 Io. 
The posters were designed to communicate the key principles of the agrarian reform in ways that could be easily understood by the general population. As Héctor Béjar commented:

Some of Velasco's speeches nobody understood. What does 'the social democracy of full participation' mean?... People had heard talk of socialism and the Cuban Revolution; of the United States; but this? So his baggage of ideas was very advanced for the era, and only some forms of communication like [the posters] were intelligible. ${ }^{47}$

The inaccessibility of the government's language was partly due to its desire to avoid being labelled as either capitalist or communist. Peru was one of the earliest Latin American countries to declare a position of non-alignment in the Cold War, stating that it would pursue a 'third way'. Furthermore, ideological divisions within the government, which was formed on pragmatic rather than ideological grounds, complicated the articulation of a clear government programme. Posters, on the other hand, worked on the basis of immediate visual appeal and condensed complex ideas into a cultural 'shorthand'.

In addition to their value as a communications medium, the posters formed part of a broader use of art by the GRFA. The notion of the 'democratisation of culture' became a crucial part of the rhetoric used by the government to maintain popularity and gather support for its reforms. Perhaps the most spectacular examples of this were the Contacta art festivals that took place in July I 97 I and 1972 . Initially driven by artists such as Francisco Mariotti and Luis Arias Vera, and subsequently supported by SINAMOS, these so-called 'total art' festivals were based on an open call for participation. The advertisement for submissions declared: 'There are no limits for the imagination. "CONTACTA 72 " is an exhibition open to professionals and amateurs. Entrance for the public will be permanent and free.' 48 The festivals were staged over four days, mixing 'official' arts with experimental arts, theatre, poetry, music, cinema and traditional arts and crafts. The success of Contacta 72 led to other festivals in inland Peru, such as the Inkarri festivals in 1973. The inclusive nature of these events chimed with the views of many contemporary Peruvian artists. In an interview with a leading magazine, Oiga, in 1969, Ciro Palacios, a prominent graphic artist, commented: 'It bothers me that my works may be in some house. I would like to see them in the street. In the bienal they put a rope in front of my picture. I protested: "Why distance it from the public; let them touch". This business of "don't touch" is absurd.'49

${ }^{47}$ Interview with Héctor Béjar, a key figure within SINAMOS, I 2 April 20 ro.

${ }^{48}$ La Nueva Crónica, 8 July 1972, p. 9. Note that La Crónica had been expropriated and transformed into La Nueva Crónica, which served as an effective government mouthpiece.

49 'Entrevista: dos horas con Ciro Palacios', Oiga, 3 I 8 (April 1969), p. 33. 
There was also a positive response to government-sponsored arts events among cultural critics. Writing in 1970, Winston Orrillo gave an optimistic account of what he called the 'new art', which he believed was responding to the most pressing issue facing contemporary society: how art could help people to live better in the world. As an example of the 'new art' he cited a recent performance of Canto coral a Túpac Amaru (II), a musical piece based on a famous poem that commemorated the life of Túpac Amaru. ${ }^{5 \circ}$ The overall effect of the performance was, he wrote, 'practically a rite, a rite of the revolution made clear in its art'. ${ }^{\text {I }}$ Similarly, an account of SINAMOSsponsored puppet shows described how the children in the audience began to see 'the advent of a more beautiful world and a more lasting fraternity'. ${ }^{52}$ The belief that the arts provided a privileged site for the spread of ideology underpinned the wide variety of cultural activities supported by SINAMOS. During its first year these included a children's folkloric festival, the establishment of a theatre and school for puppetry, a week-long arts festival in Arequipa and a programme called 'New Voice of Túpac Amaru', which produced literary works based on the authors' experiences of the transition from latifundio to cooperative. 53

This use of the arts to bring about political and cultural change was not unique to Peru. Decades earlier, the revolutionary vanguard in Mexico had used secular festivals as a means to spread socialist thought, interspersing educational talks with regional songs and dances. ${ }^{54}$ There were also strong connections with the international avant-gardism of the I9IOS and I920s. However, the changed political circumstances under the GRFA gave artists a more decisive role in political mobilisation. As Ruiz Durand commented, whereas movements such as Dadaism had been 'like a macabre game', the potential political impact of art was perceived to be much greater by the I960s. 55

so Túpac Amaru II was the leader of an indigenous rebellion against colonial rule, executed by the Spanish in $178 \mathrm{I}$. He was adopted as a popular hero and emblem of the revolution by the GRFA, as will be discussed in more detail below.

${ }^{51}$ Winston Orrillo, “Canto Coral”: arte de vanguardia, arte revolucionaria', Oiga, 398 (Nov. 1970), p. 30. $\quad 52$ Sinamos Informa, Año I, Difusión ONAMS, no. 5, 1972, p. 39.

53 Sinamos Informa, Año II, Difusión ONAMS, no. 6, 1972/73, p. 52.

${ }^{54}$ Alan Knight, 'Popular Culture and the Revolutionary State in Mexico, I 9 1 0-1 940 ', Hispanic American Historical Review, 74: 3 (1 994), p. 4I 3. Interestingly, while the Mexican Revolution was strongly anticlerical and stressed the need to replace the cultural dominance of Catholicism with 'rational' socialist thought, the Peruvian Revolution was presented as a Christian one. The puppet show referred to above combined the story of the nativity with themes of agrarian reform. $\quad$ ss Interview with Jesús Ruiz Durand, 30 March 2010. 


\section{Central Features of the Agrarian Reform Posters}

One of the principal artistic influences on the agrarian reform posters was optical art or op art. Pioneered by a Hungarian-French artist, Victor Vasarely, op art used the interaction of different fields of visual perception to create optical illusions. Its use in the agrarian reform posters was motivated by Ruiz Durand's personal artistic interests and the desire to find new ways of expressing a political message. As such, the effects achieved in the posters were remarkably consistent with ideas being explored by the European avant-garde. In 1970 a Romanian artist, Mircea Milcovitch, wrote: 'I am particularly interested in the effects of optical illusions produced by a field of closely placed lines around a central shape. In addition to the array of lines giving an illusion of vibration, the central shape takes on a kind of new life. 56 Precisely this effect was used in a poster to promote the agrarian reform in Cajamarca (Figure I). A symmetrical shape (the sun) is positioned in the background, with a series of lines shooting out towards a group of campesinos in the foreground, who are depicted working the land. The correspondence between the movement of the campesinos and the sun, which appears to be rushing towards them, generates a sense of great dynamism. Equally pertinent is Milcovitch's observation that 'The interplay of the lines on the shape and of the shape on the lines gives an observer a sense of the passage of time, for the eyes to perceive the two interplays must [sic] change their concentration from one to the other.'s7 A major challenge for the representation of any revolution is how to sustain a feeling of continuous progress, as opposed to political stagnation; the use of op art effects provided an important way of expressing this idea of movement using sensory perception rather than political slogans.

A second major artistic influence on the posters was pop art. Lucy Lippard wrote that the New York pop artists saw themselves as 'the donors of a muchneeded transfusion to counteract the effects of a rarified Abstract Expressionist atmosphere'. ${ }^{8}$ This feeling of energy was recreated in Ruiz Durand's use of bright colours and bold designs, which owed much to artists like Andy Warhol. However, there is a noticeable difference in palette between the acid tones used in Warhol's Marilyn prints and the deeper colours used in the agrarian reform posters (as in, for example, Figure I; see the colour image at www.journals.cambridge.org/las). Whereas Warhol's bright pinks and yellows are drawn from mass media imagery and invoke ideas of celebrity, fame and glamour, Ruiz Durand's use of the pop art style has an altogether different effect. By depicting indigenous campesinos in a pop art style, the posters inject their protagonists with a feeling of modernity and dynamism. At the same

${ }^{56}$ Milcovitch, 'Op Art Paintings: "Metaphenomena", Leonardo, 4: 3 (1971), p. 267.

57 Ibid.

${ }^{8}$ Lucy Lippard (ed.), Pop Art (London: Thames and Hudson, 1967), pp. 84-5. 
Figure I. 'Sácale el Jugo a tu Tierra', Poster Published by the DDRA, I968-70

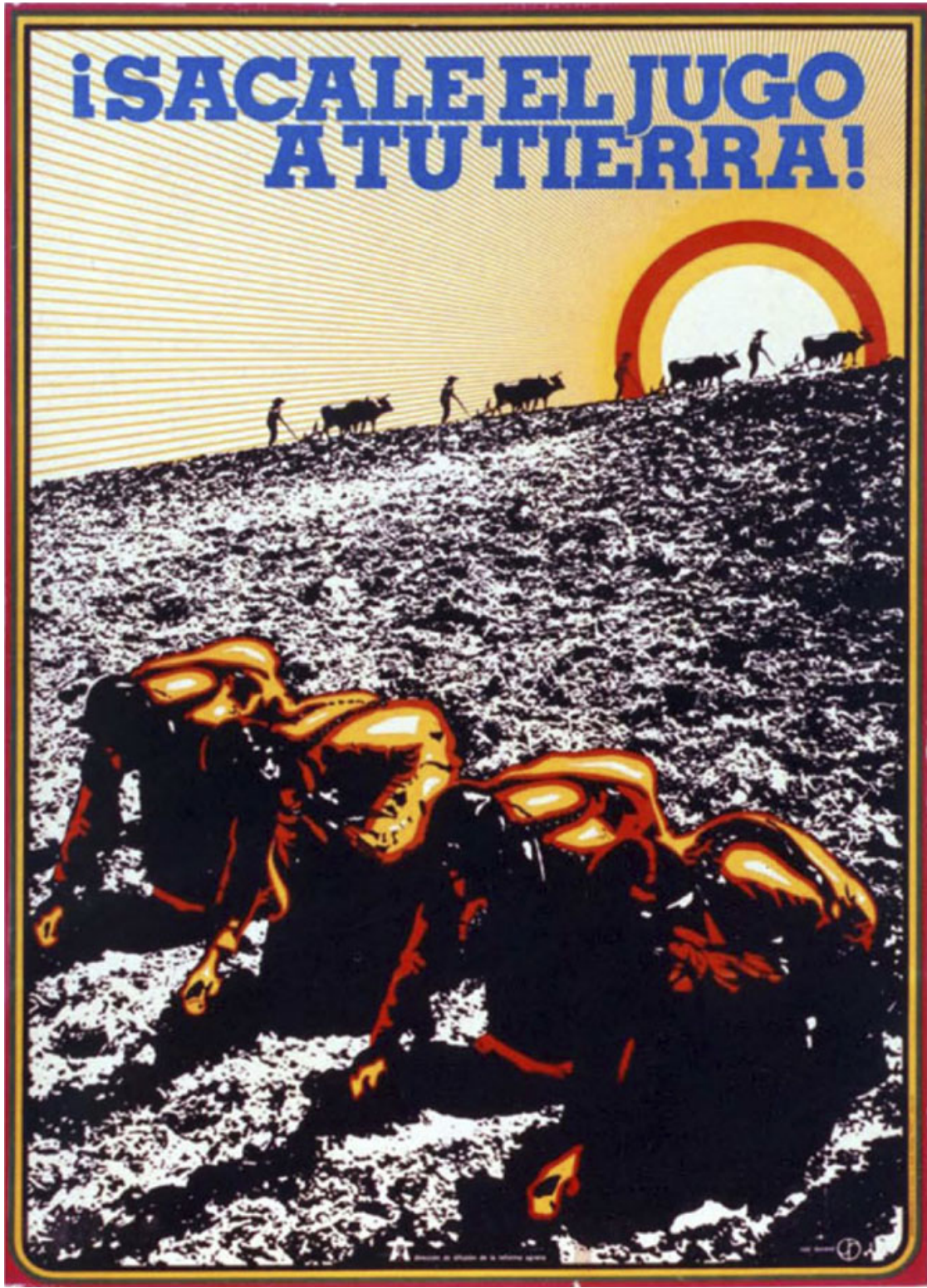

Source: Sam L. Slick Collection of Latin American and Iberian Posters, Center for South West Research, University Libraries, University of New Mexico.

time, the use of darker shades creates a depth that distinguishes the posters from the disposable, commercial nature of the New York pop style. As a recent edited volume entitled Pop Art and Vernacular Cultures demonstrates, pop art 
has shown itself to be remarkably adaptable to different international contexts, from post-independence India to apartheid-era South Africa.59 Its use in the Peruvian context tapped into a growing appetite for North American and mass consumer culture, and the rapid rate of urbanisation. In I969 a Peruvian artist, Juan Acha, wrote: 'The urban reality is the decisive one. Today the Limeño painter is surrounded by almost the same objects as his New York colleague.' ${ }^{60}$ The juxtaposition of rural scenes with such an iconically urban art form served to underline the potential for the countryside to modernise, which was one of the key aims of the agrarian reform. More specifically, the use of pop art to depict indigenous campesinos challenged the portrayal of the 'backward Indian' that had persisted among indigenista artists. The overall effect was therefore an appeal to an inclusive modernity, while capitalising upon the vibrancy of pop art and its associations with youth.

The posters present the peasantry as the protagonists of the agrarian reform. Campesinos are depicted either engaging in productive labour or directly addressing the viewer, with speech bubbles containing phrases such as 'Compadre, keep your eyes open to defend our land. The North is revolutionary ... and production is increasing!' (Figure 2). This representation of the 'common man' as the agent of revolutionary change was supported by developments in education. In Cuentos feos de la reforma agraria peruana, Enrique Mayer recounts his own involvement in producing education materials for the Velasco government, following the radical General Education Law of $1972 .{ }^{61}$ One of the principles of the new curriculum was to move away from studying traditional national heroes, the majority of whom were military, and instead encourage teachers to discover forgotten and local heroes whom their students could emulate, including campesinos who had reclaimed their lands from dishonest hacendados or lawyers who had defended falsely accused indios. ${ }^{62}$

The posters used popular myth to elevate the ideas of agrarian reform beyond the material. One of the most famous slogans read: 'i 90 years later, Túpac Amaru is winning the war' (Figure 3). Túpac Amaru II, originally José Gabriel Condorcanqui, was a Cusqueño cacique (hereditary chief) who in I 780 led a rebellion against the Spanish viceroyalty and suffered a gruesome death by quartering. As Nanda Leonardini writes: 'The revolutionary military

59 Kobena Mercer (ed.), Pop Art and Vernacular Cultures (London: Institute of International Visual Arts, 2007).

${ }^{60}$ Quoted in Gustavo Buntinx, 'Modernidades cosmopólita y andina en la vanguardia peruana', in Enrique Oteiza (ed.), Cultura y politica en los años 'óo (Buenos Aires: Instituto de Investigaciones Gino Germani, 1997), p. 270.

${ }^{61}$ For a detailed account of the Peruvian educational reform, see Judithe Bizot, Educational Reform in Peru: A Study Prepared for the International Education Reporting Service (Paris: UNESCO, 1975).

${ }^{62}$ Mayer, Cuentos feos, p. 8 I. 
Figure 2. 'Compadre, los Ojos bien Abiertos para Defender nuestra Tierra', Poster Published by the DDRA, I968-70

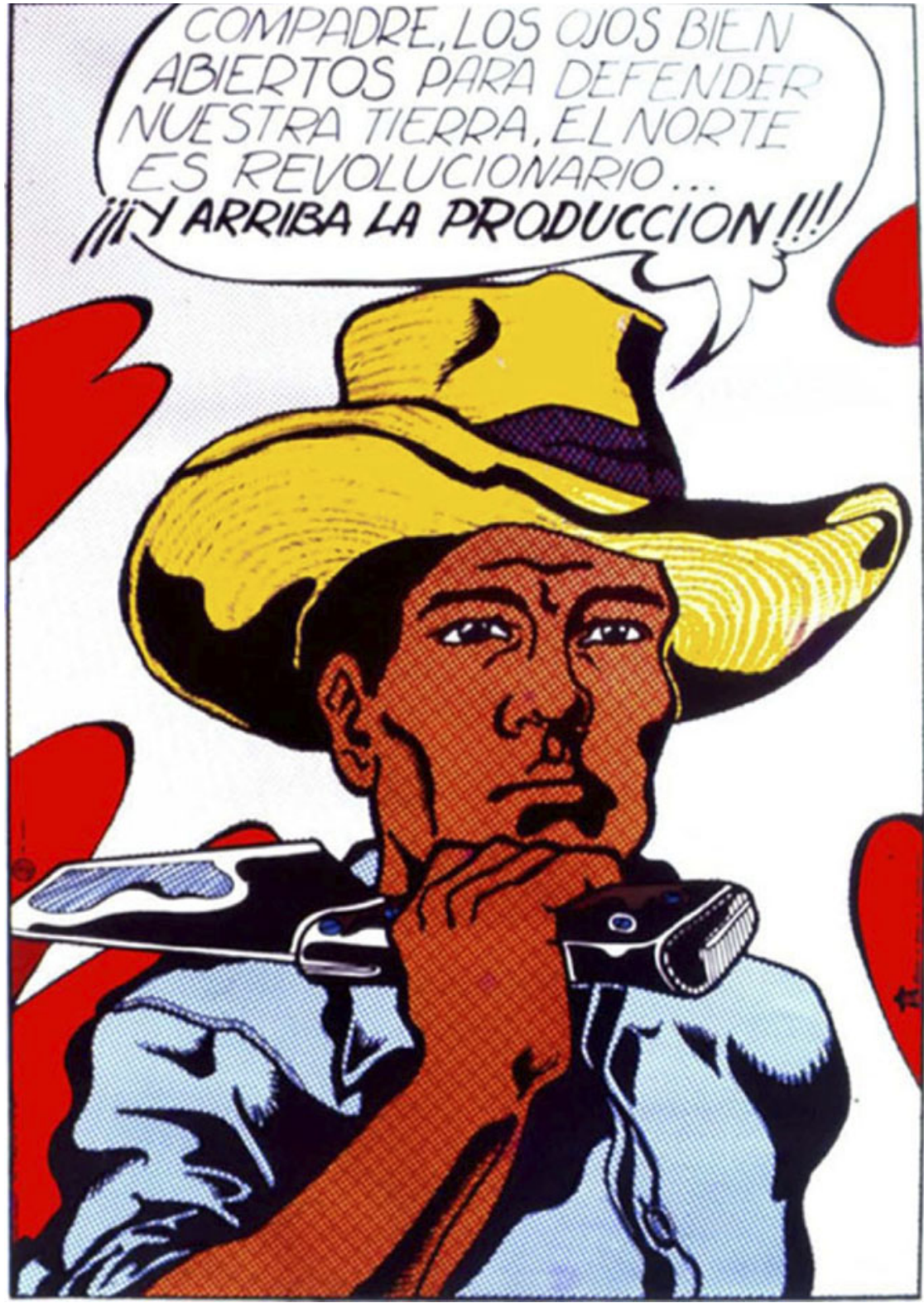

Source: Sam L. Slick Collection of Latin American and Iberian Posters, Center for South West Research, University Libraries, University of New Mexico. 
Figure 3. 'igo Años Después Tupac Amaru está Ganando la Guerra', Poster Published by the DDRA, 1968-70

\section{AÑOS DESPUESTUPACAMARU ESTA GANANDO LA GUERRA}

la causa de Túpos Amoru esto derrotondo o los que guisieron ser nuestros opresores. Los rópides ovances de la relorma agraria y de la revolución estón llevando la imagen y el espiritu de Tupac Amaru por todo el Peru .

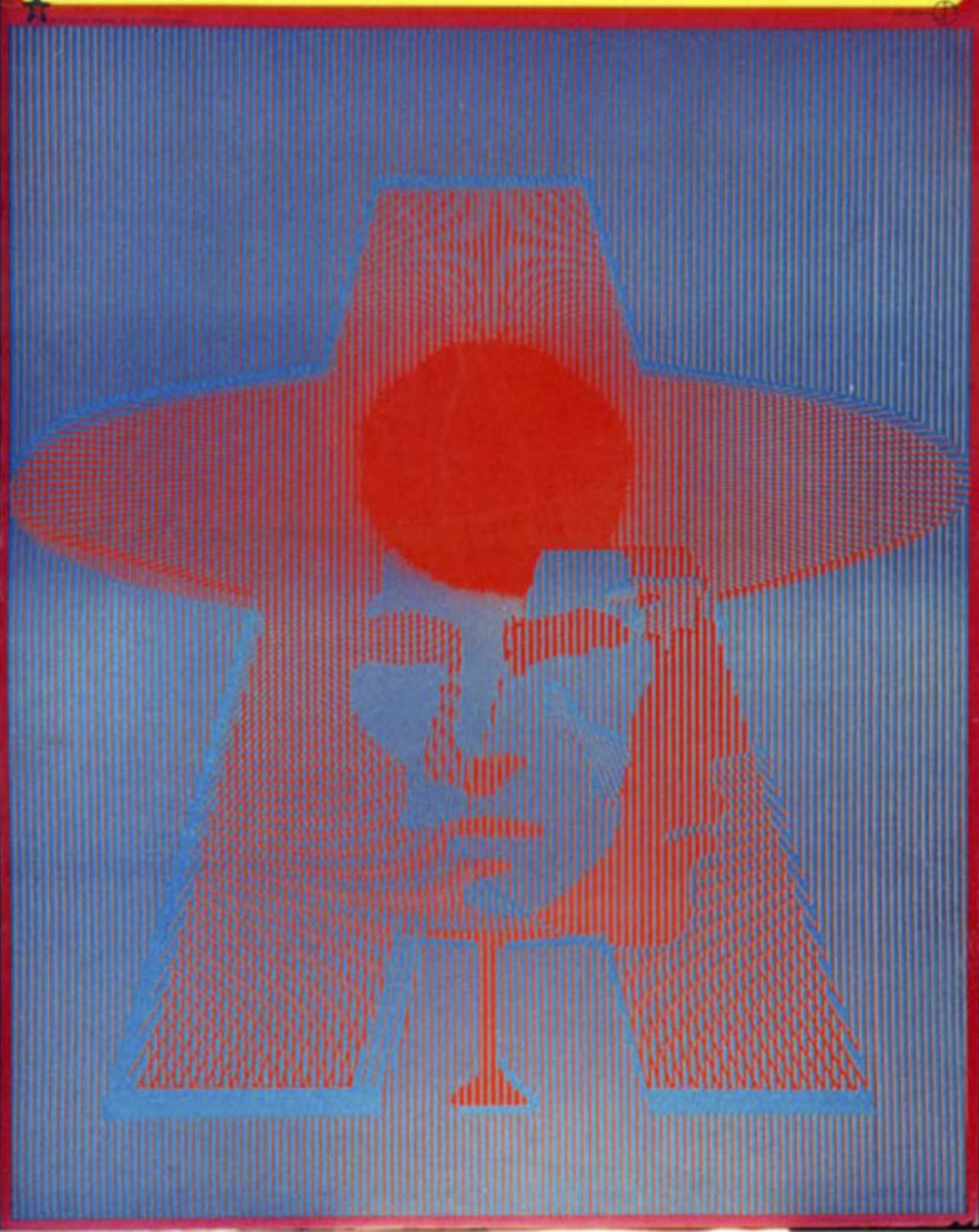

Source: Sam L. Slick Collection of Latin American and Iberian Posters, Center for South West Research, University Libraries, University of New Mexico. 
government raised this image as an ideal of someone who, like them, also questioned the established system in pursuit of the citizenship and economic rights of the people oppressed by an uninterested elite. ${ }^{63}$ Not only was Túpac Amaru a popular hero on account of his rebellious deeds, he also embodied the belief that the spirit of the Incas had lived on in the Peruvian population following the Spanish conquest. Condorcanqui had adopted the name Túpac Amaru as a deliberate attempt to associate himself with the Inca lineage, and claimed direct descent from the last Inca king. At a more literal level, the myth of Inkarri held that the last Inca ruler, Atahualpa, whose body was buried in parts across Peru, was regenerating underground and would return to the surface to restore harmony to the Inca kingdom. ${ }^{64}$ The representation of the agrarian reform as a continuation of Túpac Amaru's struggle was therefore an allusion both to a historic tradition of authentic popular rebellion and to the myth of the Inca spirit. The subtitle of the poster shown in Figure 3 reads: 'The cause of Túpac Amaru is defeating those who wanted to be our oppressors. The rapid advances of the agrarian reform and the revolution are bringing the image and the spirit of Túpac Amaru to all of Peru.' This text demonstrates a deliberate conflation between a historically documented figure and a popular myth, a strategy used frequently in the articulation of nationalist identities. The power of Túpac Amaru as an emblem of the revolution was heightened by the repeated use of his name and image across all aspects of public life, from the construction of new monuments, squares and streets to the expropriated haciendas; even the state-run urban supermarkets carried a stylised symbol of Túpac Amaru. ${ }^{65}$

As well as incorporating Túpac Amaru into their slogans, the posters produced an iconic visual representation of him that was one of the binding images of the revolution. This version of Túpac Amaru was based on the one printed in schoolbooks, where he appeared with a tie and sombrero. However, as Gustavo Buntinx has noted, Ruiz Durand was interested not in the accuracy of the image but rather in its social existence, its 'massive condition'. ${ }^{66}$ These attributes were successfully stylised to establish a symbolic identification. The success of the image as a symbol was evidenced both by the scale and range of its use and by the controversy to which it gave rise in the media. Beginning in I 972 , there was a sustained debate across a number of different newspapers on whether the Velasquista portrayal of Túpac Amaru was historically accurate. Some commentators raised doubts about whether Túpac Amaru, as an

${ }^{63}$ Nanda Leonardini, 'Identidad, ideología e iconografía republicana en el Perú', Arbor: Ciencia, Pensamiento y Cultura, i 85: 740 (2009), p. I 265.

${ }^{64}$ Gustavo Buntinx, 'Pintando el horror: sobre memorias de la ira y otros momentos en la obra de Jesús Ruiz Durand', in Hamann et al. (eds.), Batallas por la memoria, p. 3 I 8.

${ }^{65}$ Mayer, Cuentos feos, p. 82.

${ }^{66}$ Buntinx, 'Modernidades cosmopólita y andina', p. 279. 
eighteenth-century cacique, would have worn the hat that formed such a central part of the logo. Others viewed such speculation as an attempt to undermine the revolution. For example, beneath the headline, 'It is necessary to maintain the symbol', an editorial in Expreso commented: 'The reader will have noticed that in the same way as the poetry of Vallejo more deeply penetrates the heart of the Peruvian people, the figure of Túpac Amaru emerges with more and more force and eloquence, no longer as a being of legend, but as an active presence.' ${ }^{67}$ This idea of Túpac Amaru as an 'active presence' was expressed visually in the posters through the semi-figurative nature of the image, in which only Túpac Amaru's face is depicted, and even this is void of any realist flourishes (Figure 3). This creates a more powerful representation than the one commonly seen in storybooks.

Alongside the use of popular symbols, there was a more subtle incorporation of Andean iconography in the posters. For example, the sun features prominently in many of the posters, a reference to its significance under Inca rule, when it was the focus of worship and formed an important part of Inca mythology. Similarly, the outline of the Andean cross can be identified in one of the posters, within an abstract globe formation beneath the slogan 'Reforma Agraria en el Perú: a fondo!!' (Figure 4). Buntinx notes that the latter poster was originally designed for the diplomatic and cultural circuit abroad, which, he suggests, 'might explain its concentrated, virtually abstract symbolism'. Whereas the posters bearing the figure of Túpac Amaru drew on a shared familiarity with his image established through national textbooks, this poster employed 'an almost esoteric symbolism, but [was] no less political for that'. ${ }^{68}$

In a passage quoted earlier, Evans and Donald suggest that posters are 'geared to instant comprehension by a large proportion of the population', using 'shortcuts to create an immediate political or emotional impression'. ${ }^{69}$ In the Peruvian case, however, this use of posters was problematic since the country was (and is) characterised by huge diversity. The DDRA recognised a need to adapt its presentation of political messages for different regional populations. As Ruiz Durand commented, 'You are not going to take those [posters] from the north, to the south; it's another people. They see things in another way. ${ }^{\circ}{ }^{\circ}$ For this reason he worked from photographs, allowing him to tailor his designs to the particular region in which a poster was to be circulated. Close attention was paid to producing representations of the campesino that would resonate with local populations, from the mestizo man with a hat and machete typical of the northern sugar-cane worker (Figure 2) to the indigenous man wearing a traditional Cusqueño hat and poncho (Figure 5).

\footnotetext{
${ }^{67}$ Expreso, 5 Jan. 1971. $\quad{ }^{68}$ Buntinx, 'Modernidades cosmopolita y andina', p. 279.

${ }^{69}$ Evans and Donald (eds.), Picturing Power, p. I 8.

70 Interview with Jesús Ruiz Durand, 30 March 20 Io.
} 
Figure 4. 'Reforma Agraria en el Peru: A fondo!!', Poster Published by the $D D R A$, I968-70
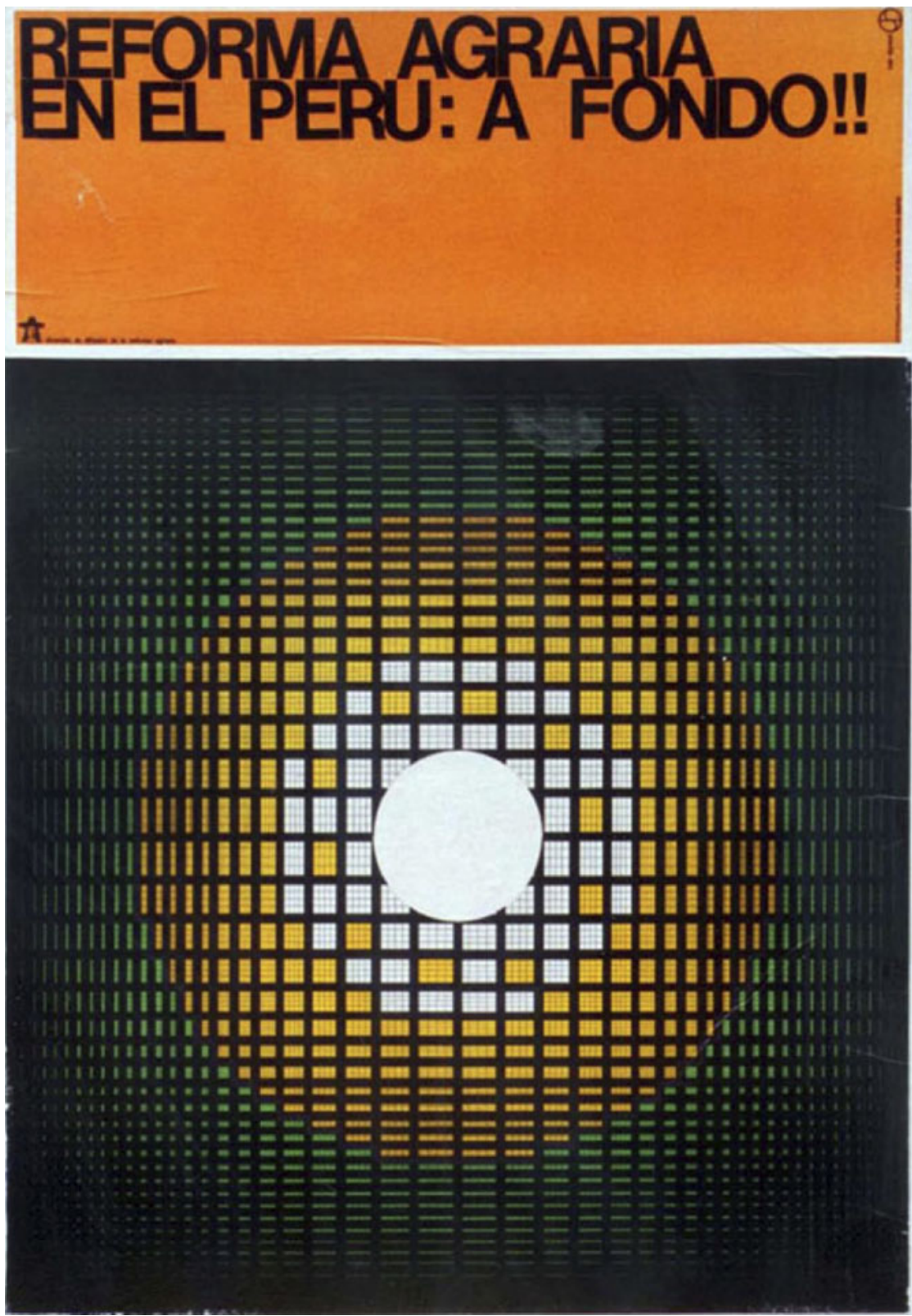

Source: Sam L. Slick Collection of Latin American and Iberian Posters, Center for South West Research, University Libraries, University of New Mexico. 
Figure 5. 'No Pagues por la Justicia', Poster Published by the DDRA, I968-70

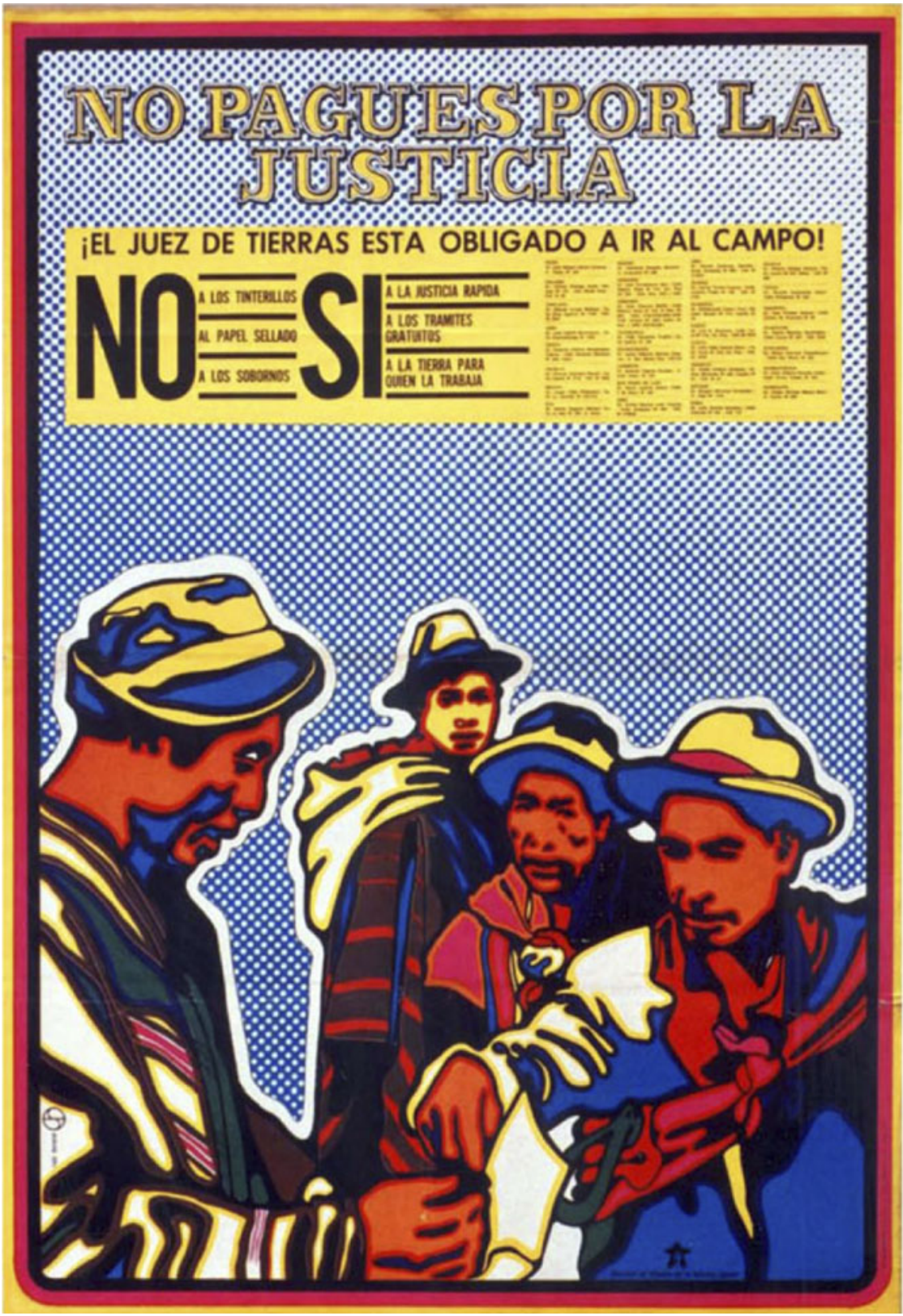

Source: Sam L. Slick Collection of Latin American and Iberian Posters, Center for South West Research, University Libraries, University of New Mexico. 
The language used in the posters reflected similar variations. For example, the term 'compadre' had greater resonance on the northern sugar plantations, where there was a strong history of unionisation, than on the traditional haciendas in the highlands.

This analysis demonstrates the multiple levels on which these posters operated. As Susan Sontag has written, 'The point of the poster may be its "message": the advertisement, the announcement, the slogan. But what is recognised as an effective poster is one that transcends its utility in delivering that message. ${ }^{71}$ It is likely that certain elements achieved greater recognition than others, but the main purpose here has been to unpack the complex visual language that was deployed to inspire popular support. This complexity was driven by an ideological commitment to political communication and mobilisation, rather than a doctrinaire propaganda remit. In an interview in 1975, Ruiz Durand described his initial feelings about working in the DDRA: 'I felt that, visually, one could realise something similar to what had worked well in Cuba, with a lot of success internationally, in terms of artistic production and in terms of the effective social communication of the message.' 72 This dual concern for artistic innovation and social communication is clearly present in the posters, which continue to resonate today.

\section{Fragmented Images: The Presence of Social Tensions in the Posters}

Gonzalo Portocarrero argues that 'Velasco fought not so much with the oligarchy, as he perhaps thought, but with the unresolved antagonisms of Peruvian society, with the fragmentation and ungovernability of a society that has not arrived at a valid system of authority, where there is no sentiment of community that allows trust.' 73 These antagonisms complicated the process of popular mobilisation, particularly with regard to the agrarian reform. The range of imagery used in the posters reflects a tension between the desire to create a new form of egalitarian politics and the need to mobilise people on the basis of particular social, ethnic or regional identities. The two Lichtensteinstyle pop art images (Figures 2 and 8 ) are particularly lifelike in their representations of the 'revolutionary' worker, encouraging the viewer to identify directly with the individual in the poster. The posters' use of the informal 'tu' similarly encourages a process of identification. More broadly, the posters evoke a shared campesino identity, firmly located in the rural environment. By contrast, a number of the posters also use abstract forms that move away from specific identities and interests, to convey the reform's significance in

${ }^{71}$ Sontag, The Art of Revolution, p. xii.

${ }_{72}$ Maruja Barrig, 'La pintura es un arte caduco', Mundial, 33 (Lima, 1975), pp. 53-6.

73 Portocarrero, 'Memorias del velasquismo', p. 247. 
structural terms. For example, a poster celebrating the transfer of sugar estates from private to cooperative ownership (Figure 6) features a sugar cane worker marching across a background of op art dots. While walking forwards he looks over his shoulder, as if in anticipation of those following behind. Depicted using psychedelic block colour and heavy outlines, the figure is transposed from a specific context onto an aesthetic (op art) plane embodying social progress at a general level. The accompanying slogan situates the image within a broader struggle against social and economic oppression, triumphantly declaring: 'Sugar ... the first industry without masters on the American continent.' Thus, while some posters make appeals on the basis of identity politics, others also encourage a transition towards structural change in which collective concerns are of primary importance.

By using both figurative and abstract representation, the posters sought to position local actions of the agrarian reform within a broader, universalist political agenda. However, the government's aim of a more just system of land distribution did not necessarily correlate with popular desire for individual land ownership. José María Caballero noted that while there was great enthusiasm for the agrarian reform, many campesinos were disappointed with its material benefits: 'In most instances cooperative members did not want - and still do not want - the cooperative (although they normally prefer it to the hacienda); instead, they definitely favour land distribution.' 74 Though there was, to an extent, an ideological imperative towards shared ownership, it was mainly the shortage of arable land that made equal division to individuals or family units impossible. Instead, it was hoped that a cooperative structure would provide a compromise solution to campesino demands, with the added benefit that this structure would be embedded within state institutions with the power to resist the oligarchy.

A number of the slogans used in the posters convey ideas of liberation for the peasantry, such as 'We are free, the revolution is giving us land' and 'Don't pay for justice' (Figures 7 and 5). The use of psychedelic colour schemes and fluid forms creates a sense of expanse in the absence of constraint. Unlike the populist posters of the I930s, which had portrayed Haya de la Torre as the saviour of the people, the agrarian reform posters deliberately focus on the peasants as agents. ${ }^{75}$ This formed part of Ruiz Durand's broader aspiration for a society in which the masses were 'protagonists and not only spectators of culture'. ${ }^{6}$ The use of speech bubbles allows Ruiz Durand to depict the campesino articulating, and not merely receiving, social change. Moreover, the

74 Caballero, 'From Belaúnde to Belaúnde', p. 45.

75 On the I930s, see Stein, Populism in Peru, p. 177.

${ }^{76}$ Jesús Ruiz Durand, 'El diablo en bolsa de plástico con cartelito', Sociedad y Política, I: I (1972), p. 56. 
Figure 6. 'El Azúcar: Primera Industria sin Patrones en el Continente Americano', Poster Published by the DDRA, I968-70

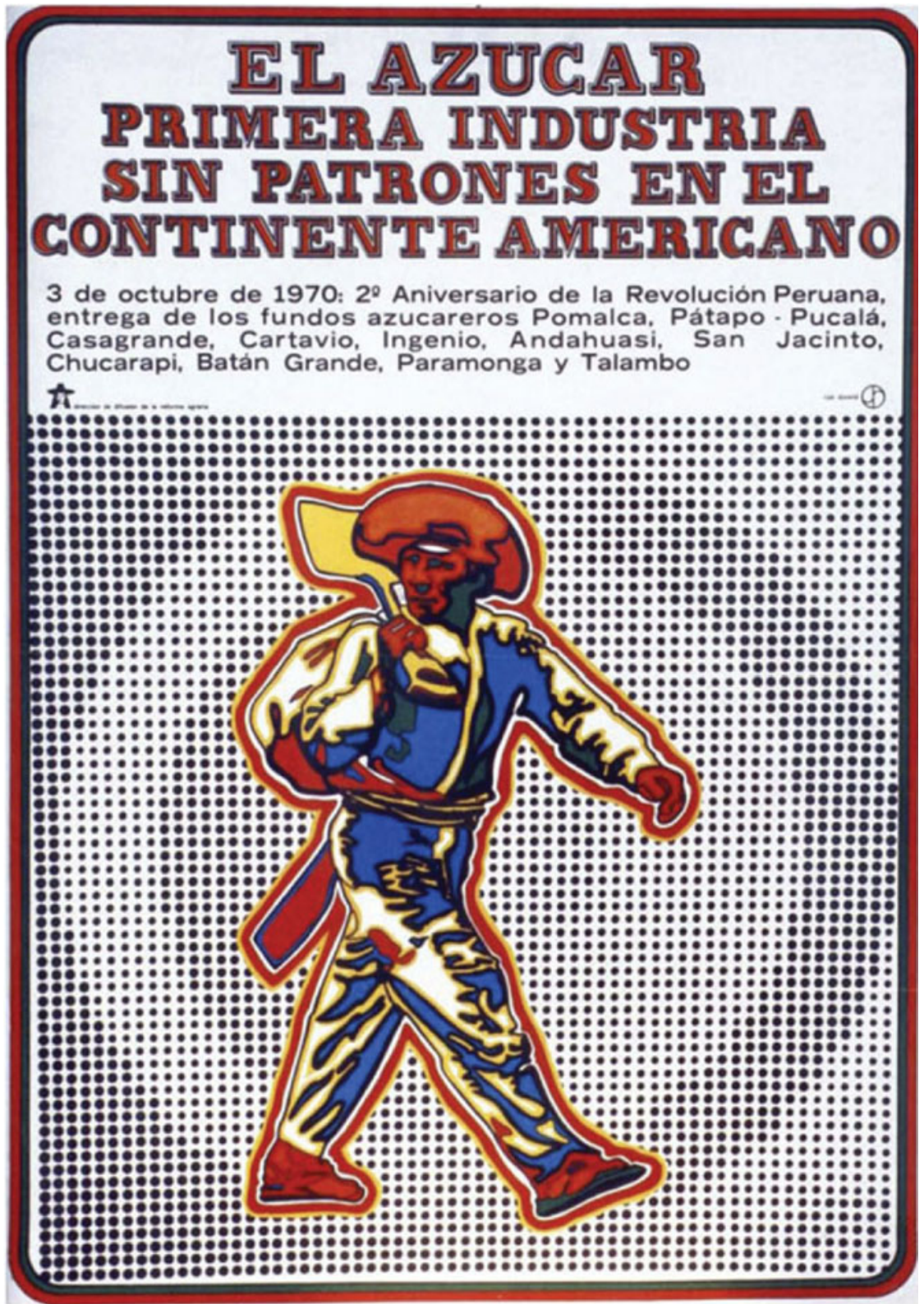

Source: made available to author by the artist, Jesús Ruiz Durand. 
Figure 7. '24 de Junio: Dia del Campesino', Poster Published by the DDRA, I968-70

\section{DE NUNIO: DIA DEL CAMPESINO}

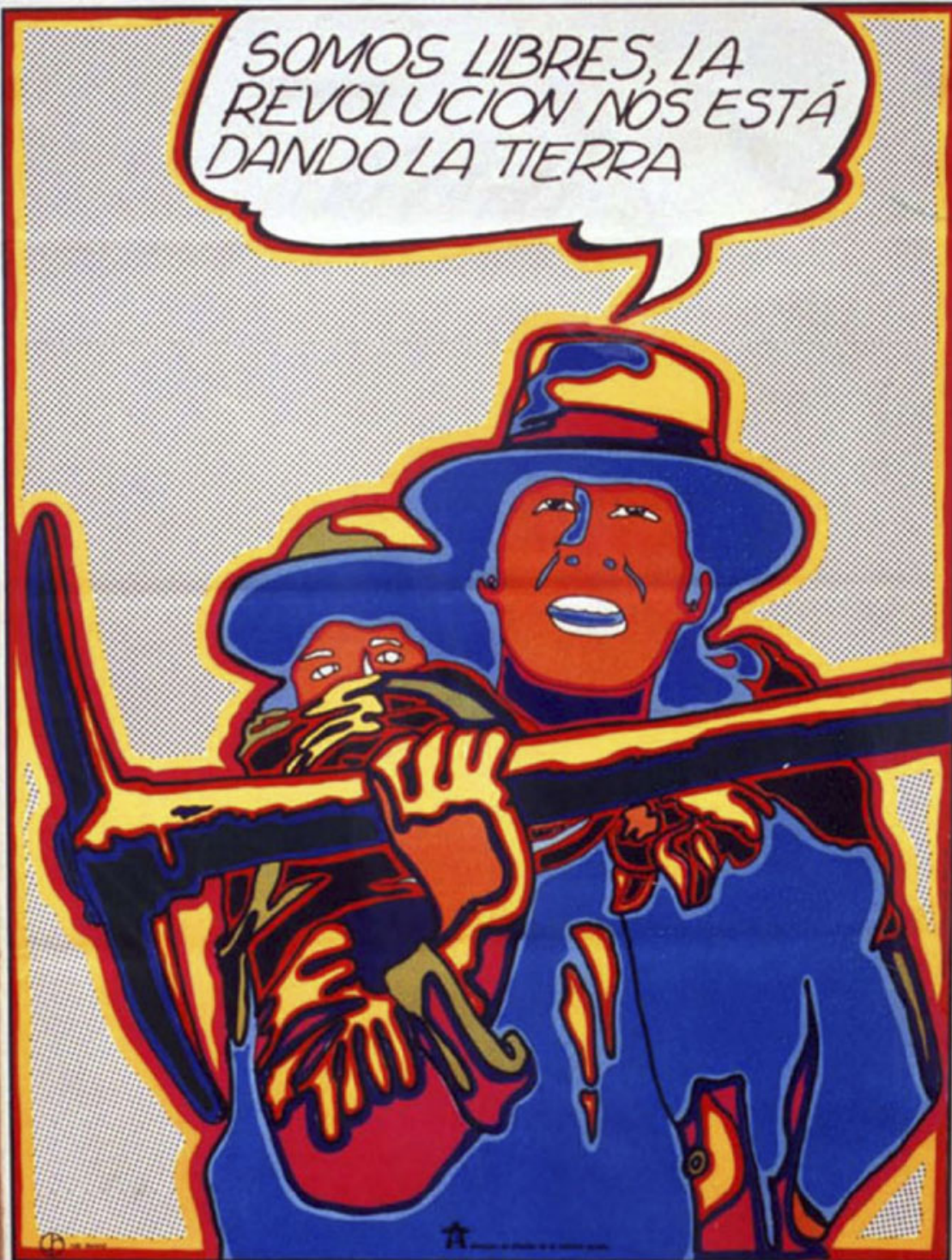

Source: Sam L. Slick Collection of Latin American and Iberian Posters, Center for South West Research, University Libraries, University of New Mexico. 
agrarian reform is presented as an assertion of the peasants' inherent rights. For example, a poster not shown here bears the slogan, 'If you work the lands of others your situation is changing', below which the text reads, 'If you are a feudatorio or worker in the countryside, nobody can remove you from the land that you work because you have a preferential right to be the owner.' 77 Significantly, the Agrarian Reform Law was announced on 24 June, the date previously celebrated as the 'Day of the Indian'. ${ }^{78}$ President Velasco declared that this date would henceforth be known officially as the 'Day of the Campesino', thus casting the reform as part of a wider movement to end the racist oppression suffered by Peru's indigenous populations.

On the other hand, the posters promote a particular, state-led form of agrarian and social change. The process of reform is clearly directed from above (the poster mentioned above informs the viewer: 'The Agrarian Reform has arrived in Cajamarca'), in contrast to the peasant-led land occupations which had proliferated during the i 960 s. Though the slogan 'Sácale el jugo a tu tierra!' ('Extract the juice from your land!', Figure I) encourages a considerable shift in the balance of power, insofar as the land should belong to those who work it, the tone is nonetheless instructive. In the accompanying image, the campesinas are shown in a uniform line, emphasising their conformity with organised production. Similarly, in the poster with the slogan 'Las mujeres norteñas estamos con la revolución' ('We northern women are with the revolution'), viewers are told that they have an obligation to act: 'you should also be present, forming a revolutionary home' (Figure 8). In this respect the posters are reminiscent of General Tantaleán's right-wing conception of popular mobilisation, discussed above, which stressed the supportive function of mass participation, directed through hierarchically organised channels. ${ }^{79}$ Moreover, the words in Figure 8 appear in a speech bubble that the artist has inserted into the mouth of a real peasant, whose photograph has been traced and coloured to create the image. Thus, both the representation and fabrication of the images present the campesino concurrently as the agent and the subject of change, simultaneously liberated and controlled by the process of agrarian reform.

The posters' representation of campesinos as the heroes of the agrarian reform was frequently inconsistent with the reality on the ground. The poster cited above (Figure 8) bears one of the most striking images of the agrarian reform series: a peasant woman holding a Peruvian flag and calling on

A feudatorio is a peasant farmer who is obliged to pay dues in the form of a portion of his produce to the landowner.

7824 June, traditionally celebrated as both the feast of St. John the Baptist and Inti Raymi, the Inca festival marking the end of the winter solstice, was renamed 'Día del Indio' by President Leguía in $192 \mathrm{I}$.

79 See North, 'Ideological Orientations of Rulers', p. 257. 
Figure 8. 'Las Mujeres Norteñas estamos con la Revolución', Poster Published by the DDRA, $1968-70$

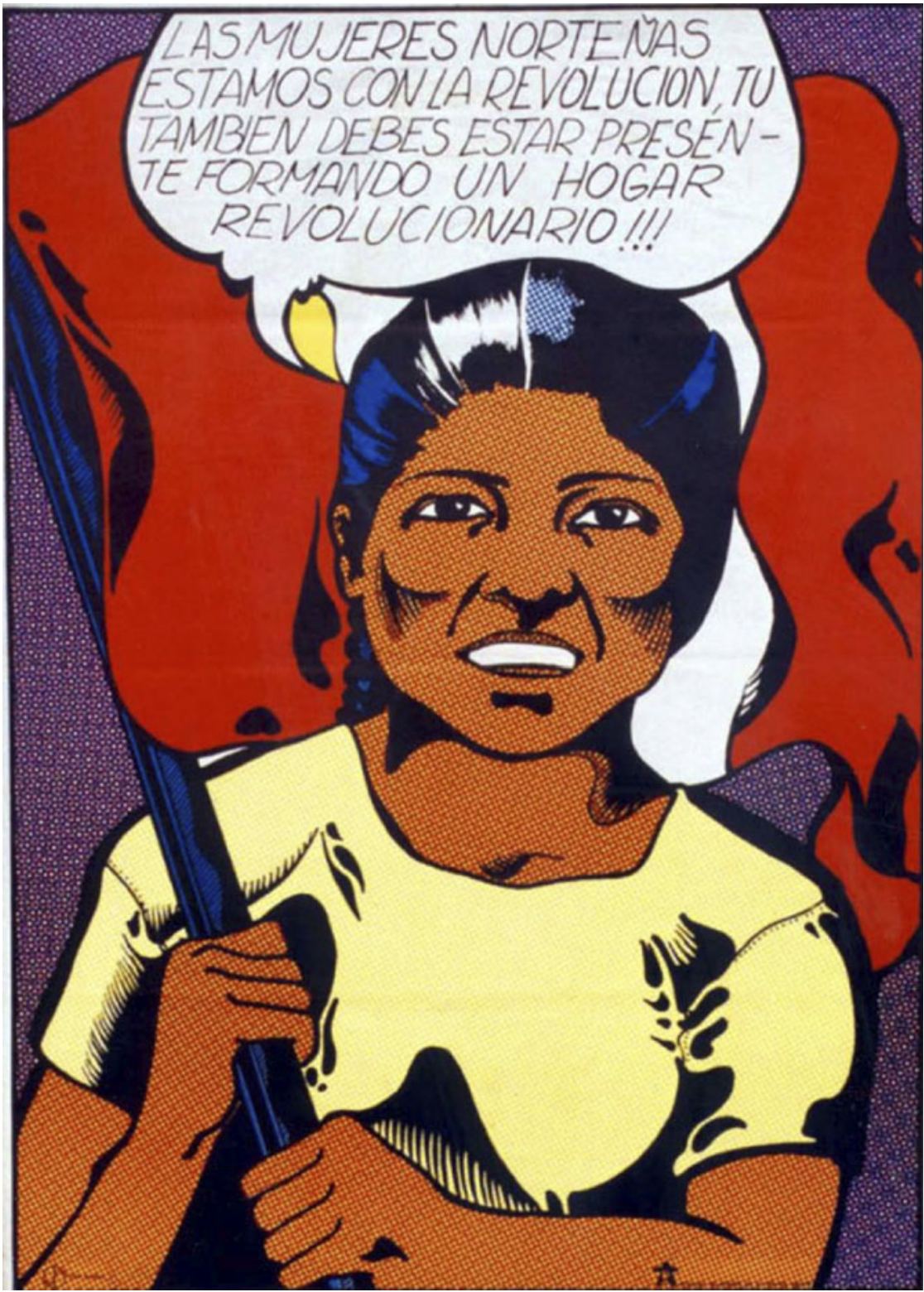

Source: Sam L. Slick Collection of Latin American and Iberian Posters, Center for South West Research, University Libraries, University of New Mexico. 
women to lend their support to the 'revolutionary home'. In fact, as Susan Bourque and Kay Warren have shown, the provisions of the Agrarian Reform Law 'undervalued women's contributions to agricultural production, left their inheritance rights vulnerable in some cases, and severely restricted their participation within the new cooperative structure' ${ }^{80}$ For example, the law granted rights to land and participation in the new cooperative structure to the male head of the household, rather than to the family as a whole. ${ }^{81}$ Thus, the posters successfully portrayed the agrarian reform as the outcome of popular action, despite considerable limitations to the extent and autonomy of peasant participation in the reform.

In Velasco's famous 24 June speech to announce the Agrarian Reform Law, he declared: 'We did not assume political power to plunder the treasury or to perpetuate injustice. To the contrary, we assumed political power to make the state into a productive instrument for the transformation of the motherland. ${ }^{\prime 2}$ Velasco deliberately distanced himself from the military governments of the past, and characterised the GRFA as an enabling force rather than a repressive one. Nevertheless, the government's ability to 'make the state into a productive instrument' was dependent on a high degree of centralisation and expansion of bureaucratic control. The GRFA established a network of microand macro-development organisations, including the Instituto Nacional de Planificación (National Planning Institute, INP), the Proyectos Integrales de Asentamiento Rural (Integrated Rural Settlement Projects, PIARs), the Proyectos Integrales de Desarrollo (Integrated Development Projects, PIDs), the Organismos Regionales de Desarrollo (Regional Development Organisms, ORDES) and SINAMOS. As Javier Ávila comments, the communities were 'no longer the object of specific projects' but were supposed to be incorporated within this system of development organisations. ${ }^{83}$ Though the intention was to create a more internally connected, efficient and fair system of development, the outcome was often excess bureaucracy and a failure to accommodate local perspectives. The fact that the offices of SINAMOS were deliberately burned down in Cusco in 1973 and in Lima in 1975, during two

${ }^{80}$ Susan Carolyn Bourque and Kay B. Warren, Women of the Andes: Patriarchy and Social Change in Two Peruvian Towns (Ann Arbor, MI: University of Michigan Press, 1981), p. I 86.

${ }_{81}$ The positioning of women within the reform process is an area in need of further research. Unfortunately, insufficient space means that I cannot deal with this important question in detail here.

82 Juan Velasco, “'The Master Will No Longer Feed Off Your Poverty”, in Orin Starn, Carlos Iván Degregori and Robin Kirk (eds.), The Peru Reader: History, Culture, Politics (2nd edition, Durham, NC, and London: Duke University Press, 2005), p. 280.

${ }^{83}$ Javier Ávila, 'Los dilemas del desarrollo: antropología y promoción en el Perú', in Carlos Iván Degregori (ed.), No hay pais más diverso: compendio de antropología peruana (Lima: Red Para el Desarrollo de las Ciencias Sociales en el Perú, 2000), p. 426. 
days of rioting, is a telling indication of the popular anger that this approach created. ${ }^{84}$

Given the distance between the type of liberation conjured by government rhetoric and the level of popular participation that occurred in practice, the posters may have been a contributory factor to growing frustration among the peasantry. Ruiz Durand ceased working for the DDRA in 1972. Among his reasons, he cites the difficulty of being confronted by campesinos who were excited by the reforms promoted in the posters but struggling to find a practical means of becoming involved:

Every time, the people, the campesinos, came and asked us: 'Well, where is the party? Where is the association? I want to sign up because we need training to be able to administer a hacienda and we have to build a political movement, and the only thing you have told us is that you are going to call.' That is, totally disarming the power of the masses. So then I simply stopped. ${ }^{85}$

The types of social organisation promoted by Velasco's government followed a Marxian, class-based approach. A particularly strong influence was Yugoslavia, where Josip Broz Tito had successfully used the language of class and economic function to create a strong sense of national solidarity in circumstances of historic ethnic division, implementing a nationalist, socialist form of government that was distinct from the communist policies of the Soviet Union. Since the Peruvian government was keen to remain non-aligned in the Cold War political context, Yugoslavia formed a major reference point in policy design and implementation. The influence of class-based approaches is particularly apparent in the government's decision to replace the term 'indio' with 'campesino'. The word 'indio' had been first used by the conquistadores to describe the indigenous inhabitants of Peru. It gained increasingly racist connotations following independence, as the criollo minority sought to maintain hegemonic control over the indigenous majority. In the 1960 s the term continued to be used to describe the country's rural inhabitants, the majority of whom were indigenous, but it was viewed as a racist anachronism. Héctor Béjar describes how the government arrived at the term 'campesino' as a way of creating a more 'rational', function-oriented description of society: 'In that period structuralism existed as a great worldwide trend of the anthropologists ... and there was a Latin American structuralist current that placed a lot of emphasis on the economy: "They are not Indians; what shall we call them? Campesinos. Because their role is to be in the countryside and produce in the countryside." 86 By removing the term 'indio' from its vocabulary, the government signalled a departure from a history of racist oppression and promoted a productive agricultural class.

${ }^{84}$ Mayer, Cuentos feos, p. $34 . \quad{ }^{85}$ Interview with Jesús Ruiz Durand, 30 March 20 Io.
${ }^{86}$ Interview with Héctor Béjar, i 2 April 20 I0. 
However, the fact that the term 'campesino' was understood as the renaming of a racially defined group ("They are not Indians; what shall we call them?') indicates the limited extent to which racist ideas of the social 'other' were challenged. In her study of the changing terms used among Peruvian intellectuals to discuss race, Marisol de la Cadena observed that "class" definitions overlapped with previous geographic and idealist definitions of "race," and continued to be built in reference to the environment, which included labor conditions' ${ }^{87}$ We can see this tendency in the imagery used in many of the posters. Despite the abstract treatment of the human figures depicted in the posters, they are still clearly identifiable as campesino 'types' - for example, through the outline of a traditional hat, or a baby strapped to the back (Figure 7).

The endurance of racial concepts within an apparently egalitarian political discourse is also noticeable in the government's policies on the arts, namely its promotion of artesania (artisanal production). Strongly associated with its rural, Andean origins, artesanía had previously been dismissed by the art establishment as lacking the creativity of formal or modern art. By contrast, the Velasco government asserted that artesanía should be viewed on the same terms as other forms of art, and not relegated to a separate sphere. A symbolic statement of this principle came in 1975, when the Instituto Nacional de Cultura (National Institute of Culture) awarded its national art prize to Joaquín López Antay, a retablista from Huamanga, prompting outrage within the art establishment. ${ }^{88}$ By awarding the national art prize to a regional artist, the government challenged the dominance of an elite circle of modern artists predominantly based in Lima, and called for a revaluation of folk art. While such actions appeared to disperse cultural barriers, in reality the government maintained a distinction between art and artesanía through its open support for neo-indigenismo. ${ }^{89}$ In common with the original indigenista movement of the 1920 s, the neo-indigenistas celebrated the so-called 'indigenous arts' as a more authentic expression of Peruvian identity. At the heart of this movement were a series of generalisations that cast 'indigenous art' as a form of traditionalism rather than a creative, adaptive medium. Thus, in the same way as the term 'campesino' was seen as loosely equivalent to 'indio', the promotion of artesanía retained a fixed understanding of 'indigenous art' that did not

${ }^{87}$ Marisol de la Cadena, 'Silent Racism and Intellectual Superiority in Peru', Bulletin of Latin American Research, 17: I (1998), p. I56.

${ }^{88}$ Max Hernández Calvo and Jorge Villacorta Chávez, Franquicias imaginarias: las opciones estéticas en las artes plásticas en el Perú de fin de siglo (Lima: Fondo Editorial de la Pontificia Universidad Católica del Perú, 2002), p. 45. A retablo is a portable altarpiece; originally based on the iconography of the Catholic Church, this art form has changed from its devotional focus to reflect folk, historical and contemporary themes.

89 Ibid., pp. 4I-2. 
correspond to contemporary artistic practice. $9^{\circ}$ Although the government tried to break down established cultural hierarchies and grant artesanía the same status as the fine arts, it did so on a segregated basis that continued to define artesanía in essentialist, ethnic terms.

\section{Conclusion}

In contrast to previous military governments, led by a single caudillo figure and concerned with preserving the status quo, the GRFA emerged from an institutional shift towards social and economic interventionism and was united by a commitment to delivering agrarian reform. Anxious to avoid the political weakness and instability that had characterised Peruvian party politics during the twentieth century, the GRFA proposed a system without parties and was deeply attentive to questions of popular mobilisation. While critics have been quick to identify the Velasco government as authoritarian and corporatist, it has been argued here that the government's approach was more open and less premeditated than has often been suggested. The scale and ambition of the GRFA's agrarian reform required a similarly massive effort to mobilise popular support. The agrarian reform posters appeared during a particularly fluid period when the government's ideas on popular mobilisation were still forming. As the work of a team of avant-garde artists and writers, they were both creative and experimental.

The posters were produced during the 'golden age of the poster' in the Americas. ${ }^{91}$ Expanding communications networks and new printing techniques resulted in a proliferation of street posters throughout the continent, particularly in the wake of the Cuban Revolution. Posters were a particularly effective means of promoting the agrarian reform as they could be produced quickly enough to keep pace with rapid land expropriations in different areas of the country. Moreover, unlike Velasco's lengthy speeches and the opaque theoretical discussions that proliferated in other government communications, the posters were able to encapsulate complex political ideas in just a few images. This article has examined the particular visual effects and references that made the posters such a striking example of government propaganda. The use of pop and op art effects captured a feeling of modernity and change, while the evocation of popular heroes, both historic (Túpac Amaru) and contemporary (the revolutionary campesino), helped cast the agrarian reform as a social transformation carried out in the name of the people. By fusing aspects of Peruvian society that had previously been separated into distinct cultural spheres (for example, the indigenous campesino portrayed using an urban, pop art style), the posters contributed to what Gustavo Buntinx has 
described as the struggle to 'establish the necessary community of images'.92 Yet they also reflected major contradictions in the revolutionary movement, such as the need to stimulate participation while establishing political control, the tension between individual interests and a system of agrarian cooperatives, and the struggle between a radical, class-based movement and the statist socialist models pioneered in Eastern Europe.

The posters varied their artistic approach to identify with a diverse population, from regionally specific representations of the peasantry to the use of psychedelic colour that captured the widespread aspiration for modernity and change. Through the layering of different images and visual effects the posters successfully developed a political iconography that resonated with broad sectors of Peru's population. This is particularly evident in the poster entitled 'i 90 años después Túpac Amaru está ganando la guerra' (Figure 3), which combines the key techniques characterising the series into a single image. The poster's synthesis of the figurative block depiction of Túpac Amaru (inspired by pop art), its use of optical illusion, dark palette and multiple facial projection (reminiscent of Cubism), and its reference to sun worship at the centre of the image create a unique icon which is visually intense while simultaneously acting as a tangible symbol to a broad segment of Peruvian society. The fact that it was reproduced frequently on home-made placards and banners is a sign of its wide recognition and penetration of popular culture. As Enrique Mayer has commented, images of Túpac Amaru had an aura similar to the emblem of Che Guevara in Cuba or Augusto César Sandino in Nicaragua. ${ }^{93}$ Interestingly, this same symbol is currently being used by social protest groups in Argentina. ${ }^{94}$ In an exhibition at Lima Art Museum in 2010, it appeared again amid an interactive art display in which the public were invited to graffiti a blank canvas.95

Through the introduction of new evidence and a detailed exploration of visual propaganda, this article has challenged existing accounts of political communication during the Velasco era, showing the sophistication and depth of the government's attempts to foster social participation. Posters rely upon shared cultural reference points to communicate their meaning immediately. ${ }^{96}$ Though this article has shown that this resort to immediacy and recognisability is equally evident in the agrarian reform posters, it has also

92 Gustavo Buntinx, Utopia y ruinas. Jesús Ruiz Durand: fragmentos de una retrospectiva (Lima, 2005). This pamphlet was produced to accompany an exhibition of the same name.

${ }_{93}$ Mayer, Cuentos feos, p. 82.

94 The Organización Barrial Túpac Amaru (Túpac Amaru Neighbourhood Organization), based in Buenos Aires, uses the agrarian reform logo alongside images of Eva Perón and Che Guevara, giving some idea of its popular appeal: see www.tupacamaru.org.ar.

95 Sculptural installation by José Carlos Martinat, Monumentos vandalizables: abstracción de Poder III, 8 April-20 June 2010.

${ }^{96}$ Evans and Donald (eds.), Picturing Power, p. I 8. 
demonstrated that the appeal to shared reference points was problematic due to Peru's heterogeneity. To a large extent this accounts for the posters' visual complexity, noted by David Craven (cited in the introduction to this article). In this respect the posters succeeded in generating a sense of immediacy by weaving together distinct regional and socio-economic histories, and cultivating a national momentum for change by depicting a continuity that had not previously existed. Yet, as a product of central government preoccupied by the relation of the state to the regions, the posters failed to represent the view localities held of their own situation within the state. Further contributions could be made to the field by studying the propaganda produced locally - unfortunately, however, the vast majority of SINAMOS documentation was destroyed as part of the Morales Bermúdez government's deliberate dismantling of the Velasco legacy. Alternatives to documentary history would thus need to be found in order to pursue this line of research further.

\section{Spanish and Portuguese abstracts}

Spanish abstract. Las dictaduras militares latinoamericanas del siglo XX con frecuencia fueron derechistas, elitistas y violentas. Una notable excepción fue el gobierno militar izquierdista peruano de Juan Velasco Alvarado. Aún más excepcional fue el uso gubernamental de medios visuales. Entre 1968 y 1970 produjo cerca de 20 afiches, impresos en ediciones de 50,000 y 200,000 unidades, para promover la radical Reforma Agraria. Estos pósters proveen una representación vibrante de aspectos ideológicos de la reforma agraria de lo cual hay pocos estudios. Una exploración detallada de la comunicación visual muestra que el gobierno utilizó una estética y una propaganda estéticamente sofisticada y símbolos para alentar la participación social en la reforma.

Spanish keywords: Perú, Juan Velasco Alvarado, reforma agraria, afiches, arte pop, arte op

Portuguese abstract. As ditaduras militares latino-americanas do século XX geralmente foram de direita, elitistas e violentas. Uma exceção marcante foi o governo militar peruano de esquerda de Juan Velasco Alvarado. Mais excepcional ainda foi o uso da mídia visual pelo governo. Entre 1968 e 1970 produziu-se aproximadamente 20 cartazes, impressos em edições de 50 mil a 200 mil unidades para promover a radical Lei da Reforma Agrária. Esses cartazes apresentam vibrantes representações dos aspectos ideológicos da reforma agrária, ainda não suficientemente estudados. Uma detalhada examinação da comunicação visual demonstra que o governo utilizou símbolos e propaganda esteticamente sofisticados para incentivar uma participação social na reforma.

Portuguese keywords: Peru, Juan Velasco Alvarado, reforma agrária, cartazes, arte pop, arte óptica 